OPEN ACCESS

Edited by:

Narasimham L. Parinandi,

The Ohio State University,

United States

Reviewed by:

Sanjay Varikuti,

Johnson and Johnson Pharmaceutical Research and Development,

United States

Sathya Dev Unudurthi,

Masonic Medical Research Institute

(MMRI), United States

*Correspondence:

Wenru Su

suwr3@mail.sysu.edu.cn

Xianggui Wang

wangxg@csu.edu.cn

tThese authors have contributed equally to this work

Specialty section: This article was submitted to Translational Pharmacology, a section of the journa

Frontiers in Pharmacology

Received: 12 July 2021 Accepted: 19 October 2021 Published: 02 November 2021

Citation:

Jiang Q, Li Z, Tao T, Duan R, Wang X and Su W (2021) TNF- $\alpha$ in Uveitis:

From Bench to Clinic.

Front. Pharmacol. 12:740057. doi: 10.3389/fphar.2021.740057

\section{TNF-a in Uveitis: From Bench to Clinic}

\author{
Qi Jiang ${ }^{1 \dagger}$, Zhaohuai $\mathrm{Li}^{1 \dagger}$, Tianyu Tao ${ }^{1}$, Runping Duan ${ }^{1}$, Xianggui Wang ${ }^{2,3 *}$ and Wenru Su ${ }^{1 *}$ \\ ${ }^{1}$ State Key Laboratory of Ophthalmology, Zhongshan Ophthalmic Center, Sun Yat-sen University, Guangzhou, China, ${ }^{2}$ Eye \\ Center of Xiangya Hospital, Central South University, Changsha, China, ${ }^{3}$ Hunan Key Laboratory of Ophthalmology, Changsha, \\ China
}

Uveitis is an inflammation of the iris, ciliary body, vitreous, retina, or choroid, which has been shown to be the first manifestation of numerous systemic diseases. Studies about the immunopathogenesis and treatment of uveitis are helpful to comprehend systemic autoimmune diseases, and delay the progression of systemic autoimmune diseases, respectively. Tumor necrosis factor-alpha (TNF- $\alpha$ ), a pleiotropic cytokine, plays a pivotal role in intraocular inflammation based on experimental and clinical data. Evidence of the feasibility of using anti-TNF- $\alpha$ agents for uveitis management has increased. Although there are numerous studies on TNF- $\alpha$ in various autoimmune diseases, the pathological mechanism and research progress of TNF- $\alpha$ in uveitis have not been reviewed. Therefore, the objective of this review is to provide a background on the role of TNF- $\alpha$ in the immunopathogenesis of uveitis, as well as from bench to clinical research progress, to better guide TNF- $\alpha$-based therapeutics for uveitis.

Keywords: uveitis, TNF- $\alpha$, anti-TNF- $\alpha$ agents, infliximab, adalimumab, golimumab, certolizumab pegol, experimental autoimmune uveitis (EAU)

\section{INTRODUCTION}

Uveitis is a heterogeneous nosological entity. Although the uvea is defined as the middle membrane (Jabs et al., 2005) of the ocular wall comprising the iris, ciliary body and choroid, the term uveitis is broad and encompasses inflammatory damage to the uvea, retina, retinal vessels, vitreous body, and optic papilla (Figure 1). The incidence of uveitis in the United States is 52.4/100,000 population, with a prevalence of $115 / 100,000$ population (Gritz and Wong, 2004). One of the primary causes of blindness in developing countries is inefficacious control of or untreated uveitis, mainly owing to complications such as macular edema, glaucoma, and retinal ischemia (Dick et al., 2016). Uveitis is often the first manifestation of many systemic autoimmune diseases. According to recent studies, although 23-63\% of uveitis cases are idiopathic (Bodaghi et al., 2001; Jakob et al., 2009; Keino et al., 2009; Barisani-Asenbauer et al., 2012; Bajwa et al., 2015; Llorenç et al., 2015; Luca et al., 2018; Hermann et al., 2021; Sonoda et al., 2021), up to $40 \%$ of uveitis patients also have systemic autoimmune diseases. The transparency of the eye allows the vascular lesions to be observed directly with the help of certain devices. Direct visualization of the vessels allows ophthalmologists to assess the inflammatory process in depth before serious tissue damage occurs. Therefore, investigating the immunopathological mechanism of uveitis based on a better understanding of autoimmune diseases is important and enables the development of better treatment methods to decrease the blindness rate and control the progression of autoimmune diseases.

Tumor necrosis factor-alpha (TNF- $\alpha$ ) is an acidic protein that is mainly produced by macrophages in response to infection and inflammatory irritation. It is related to chronic inflammation and tissue damage in uveitis and is critical for initiating immunity to pathogens (Vassalli, 1992). TNF receptor I (TNFR1) and TNFR2 are expressed by the intraocular pigment epithelial cells. Further, these cells can produce TNF- $\alpha$ and the matrix metalloprotease, which can 


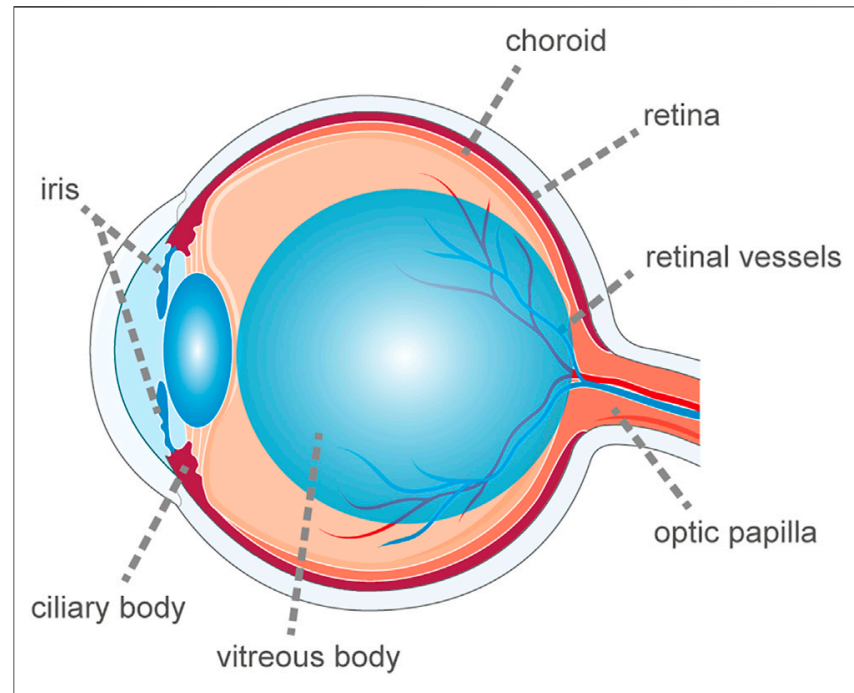

FIGURE 1 | The schematic diagram of ocular anatomy. The term uveitis is broad and encompasses inflammatory damage to the uvea, retina, retinal vessels, vitreous body and optic papilla.

cleave TNF- $\alpha$ from the transmembrane form into a soluble form circulating within the eye. These factors constitute the basis through which TNF- $\alpha$ can cause intraocular inflammation. TNF- $\alpha$ is of vital importance for the intraocular immune reaction, which is referred to as "anterior chamber associated immune deviation" and for the autoregulation of intraocular cell apoptosis (MacEwan, 2002).

Although uveitis represents a group of intraocular inflammatory conditions, each with its own phenotypic heterogeneity, the commonality is the increased expression of TNF- $\alpha$ in both the serum and aqueous humor. Over the past decade, studies have increasingly emphasized the effectiveness of anti-TNF- $\alpha$ agents for patients with uveitis. Although there are numerous studies on TNF- $\alpha$ in various autoimmune diseases, the pathological mechanism and research progress with respect to the role of TNF- $\alpha$ in uveitis have not been reviewed. Thus, in this review, we aimed to provide a background of the role of TNF- $\alpha$ in the immunopathogenesis of uveitis and an account of the progress from bench to clinical research progress to better guide TNF- $\alpha$-based therapeutics for uveitis.

\section{THE ORIGIN AND BIOLOGY OF TUMOR NECROSIS FACTOR-ALPHA}

TNF- $\alpha$ is a cytokine with diverse functions, including inflammation, immunity, cellular communication, cell differentiation, cell death, and survival, and a variety of signaling pathways. Although TNF was identified as early as 1975, the true identity of TNF was unclear until 1984 when Aggarwal et al. reported the isolation of cytotoxic factors, one of which was derived from macrophages, named TNF (Gray et al., 1984; Pennica et al., 1984; Kelker et al., 1985; O’Malley et al., 1988; Aggarwal et al., 2012). Using the same assays, Aggarwal et al. reported the isolation of a cytotoxic factor and named human TNF- $\alpha$
(Aggarwal et al., 1985). In 1990, two immunological TNF-binding proteins, namely $55 \mathrm{kDa}$ (TNFR1) and $75 \mathrm{kDa}$ (TNFR2), were identified, and subsequently, the cDNAs for both human proteins have been cloned (Hohmann et al., 1989; Schall et al., 1990).

TNF- $\alpha$ primarily exists as a trimeric transmembrane protein, transmembrane TNF- $\alpha$ (tmTNF- $\alpha$ ), which is subsequently cleaved by TNF- $\alpha$ converting enzyme (TACE; also known as ADAM17) into a soluble form (sTNF- $\alpha$ ) (Black et al., 1997). TNF- $\alpha$ has multifunctional bioactivity achieved by binding and activating two different receptors (TNFR1 and TNFR2). TNFR1, which is activated by sTNF- $\alpha$ and tmTNF- $\alpha$, is ubiquitously expressed. TNFR1 bears the death domain that allows TNFR1 to organize the molecule TNF receptor-associated death domain (TRADD), which is a vital component of the TNFR1 signaling complex. In contrast, TNFR2 expression is limited to certain cell types (e.g., immune cells and endothelial cells). TNFR2 lacks a death domain resulting in its inability to recruit TRADD, and instead, it enlists TNFR-associated factor 1 (TRAF1) and TRAF2. TNFR2 is speculated to be activated primarily by tmTNF- $\alpha$ (Grell et al., 1995; Krippner-Heidenreich et al., 2002; Bystrom et al., 2018). However, there is evidence that sTNF- $\alpha$ might induce biological effects by transferring onto TNFR1 when binding to TNFR2. TNFRs can also be cleaved by TACE to produce soluble forms (sTNFRs), which bind to sTNF- $\alpha$ to exert effects. Studies have shown that sTNFRs are significantly increased in the ocular fluids of patients with active uveitis (Sugita et al., 2007). For TNF$a$, the disparate distributions and binding characteristics to receptors are the pathological foundations for the occurrence and development of intraocular inflammation, which could indicate why systematic autoimmune diseases and uveitis have different responses to anti-TNF- $\alpha$ agents.

\section{SIGNALING PATHWAYS ACTIVATED BY TUMOR NECROSIS FACTOR-ALPHA}

When TNF- $\alpha$ binds to TNFR1, it assembles different signaling complexes consisting of the complexes I, IIa, IIb (ripoptosome), and IIc (necrosome), resulting in different functional outcomes (Pasparakis and Vandenabeele, 2015). TNF- $\alpha$ complex I signaling primarily mediates homeostatic bioactivities, which comprise tissue regeneration, cell proliferation and survival, inflammation, and immune defense. Similar effects can be caused by the combination of TNF- $\alpha$ and TNFR2, which may be related to the overlapping downstream pathways of TNFR1 signaling pathways. However, the formation of the complex IIa and IIb leads to the activation of a caspase cascade and results in apoptosis, whereas the necrosome induces necroptosis and inflammation. The signaling transduction pathways of the complexes are described briefly below and summarized in Figure 2.

\section{Tumor Necrosis Factor-Alpha Signaling in Complex I}

With the binding of TNF- $\alpha$ to TNFR1, TRADD (Hsu et al., 1995), receptor-interacting protein kinase 1 (RIPK1), TRAF2, cellular 


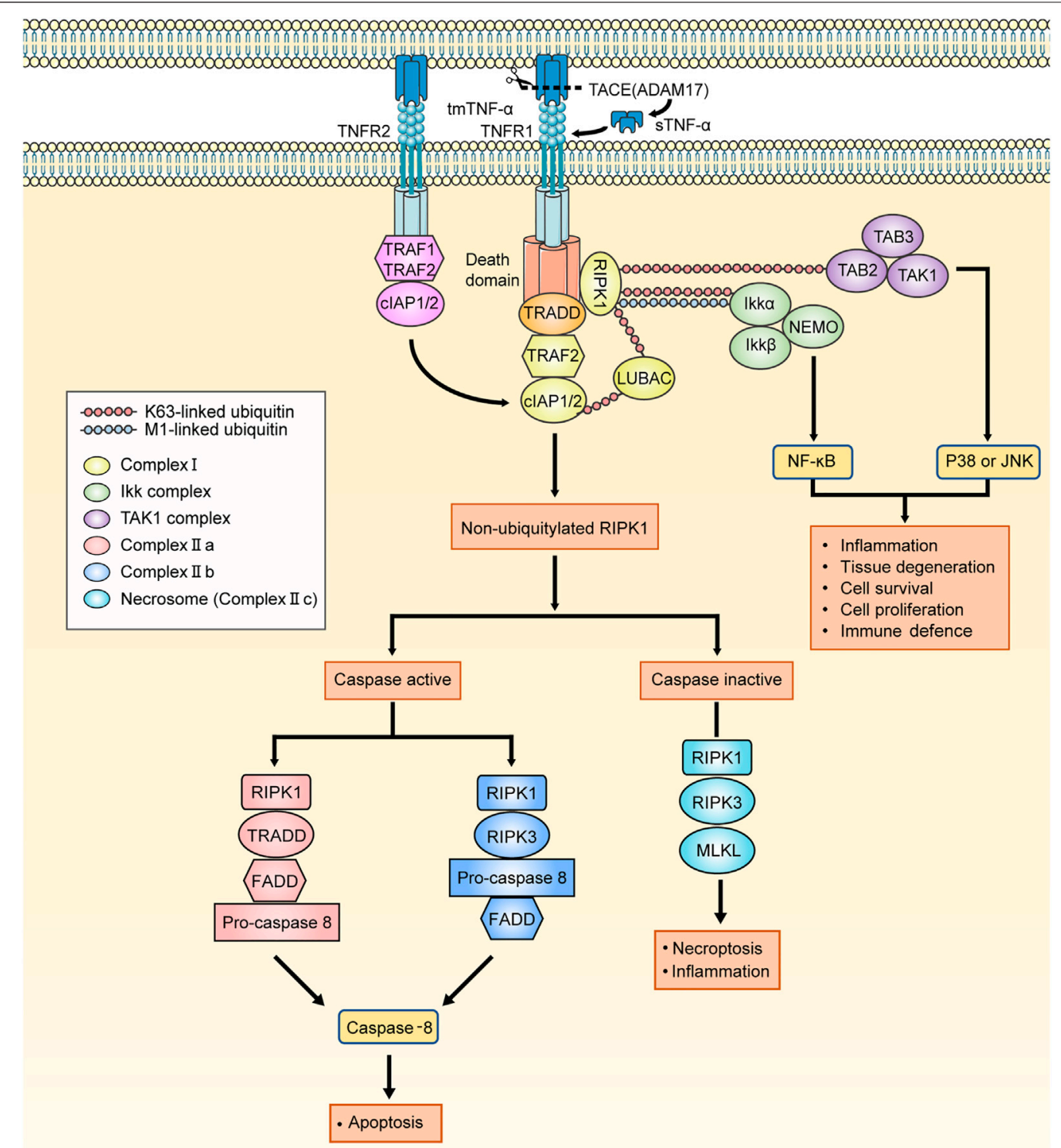

FIGURE 2 | The signaling pathways activated by TNF- $\alpha$. The tmTNF- $\alpha$ is cleaved by TACE into STNF- $\alpha$. The TNFR1 signaling is activated by both tmTNF- $\alpha$ and sTNF- $\alpha$. When the binding of TNF- $\alpha$ to TNFR1, TNFR1 ligation leads to the recruitment of TRADD, RIPK1, LUBAC, TRAF2, clAP1/2 and initiate the assembly of TNFR1 complex I. The TNFR2 signaling is almost activated by tmTNF- $\alpha$. On account of the lack of TRADD, TNFR2 binds to TRAF1/2 directly to recruit clAP1/2 and affiliate the TNFR1 signaling. The K63 ubiquitin ligase activities which is owned by cIAPs are required for LUBAC recruitment, and cIAPs add M1-linked linear polyubiquitin chains to RIPK1 which makes TAK1 complex and IKK complex assemble to respectively mediate JNK/p38 and NFkB pathways. And RIK1 deubiquitylates under conditions in which the K63-linked and M1-linked polyubiquitin chains are removed by the deubiquitylating enzyme CYLD from RIPK1. The residuum recruits TRADD, FADD and pro-caspase 8, thereby forming the complex Ila. When the cIAPs are depleted, there is no RIPK 1 is deubiquitylated and leaves residuum to recruit FADD, procaspase 8 and RIPK3, assembling complex Ilb. Following the assembly of complex II, pro-caspase 8 conducts autocatalytic cleavage, releasing active caspase 8 to trigger the implementation of the apoptotic program. When deubiquitylated RIPK1 exists but caspase is devitalized, RIPK1/3 cannot be inactivated. Instead, RIPK1 and RIPK3 cluster together to form the complex IIc (necrosome) and necroptosis program is initiated. TNFR1: TNF- $\alpha$ receptor 1 ; tmTNF- $\alpha$ : transmembrane TNF- $\alpha$; sTNF- $\alpha$ : soluble TNF- $\alpha$; TACE: the matrix metalloprotease TNF- $\alpha$ converting enzyme; TNF- $\alpha$ : tumour necrosis factor-alpha; TRADD: TNFR1-associated death domain protein; RIPK1: receptor-interacting serine/threonine-protein kinase 1; LUBAC: linear ubiquitin chain assembly complex; TRAF1/2: TNFR-associated factor 1/2; cIAP1/2: cellular inhibitor of apoptosis protein 1/2; TAK1 complex: TGF- $\beta$ activated kinase 1 complex, consisting of TAK1, TAK1-binding protein 2 (TAB2) and TAB3; IKK complex: the complex comprising kinases IKKa and IKK $\beta$, nuclear factor-kB (NF-kB) essential modulator (NEMO); JNK: Jun N-terminal kinase; CYLD: cylindromatosis; FADD: FASassociated death domain protein.

inhibitor of apoptosis proteins 1 (cIAP1), cIAP2, and linear ubiquitin chain assembly complex (LUBAC) sequentially integrate into TNFR1 to form complex I (Silke and Brink,
2010; Brenner et al., 2015). The cIAPs have ubiquitin ligase activity, which is required for LUBAC recruitment, adding M1-linked linear polyubiquitin chains to RIPK1 (Komander 
and Rape, 2012). K63-polyubiquitylated RIPK1 associates with the TAK1 complex to activate Jun N-terminal kinase (JNK) and p38-mediated signaling. Furthermore, recruitment of the K63polyubiquitylated RIPK1 and the IKK complex, which comprises kinases IKK $\alpha$ and IKK $\beta$ and nuclear factor- $\kappa B(N F-\kappa B)$ essential modulator (NEMO), activates NF- $\kappa \mathrm{B}$-mediated anti-apoptotic signaling (Micheau and Tschopp, 2003). TNFR2 lacks the death domain sequence, rendering it incapable of recruiting TRADD, and instead, it recruits TRAF1/2 and cIAP1/2 directly. The TNFR2 signaling pathway will overlap with the subsequent TNFR1 signaling pathways here.

A recent study showed that MST1 negatively regulates TNF$\alpha$-induced NF- $\kappa B$ signaling by modulating LUBAC activity (Lee et al., 2019). Another report showed that TBK1 and IKKe (NEMO, as mentioned previously herein) prevent TNFinduced cell death via RIPK1 phosphorylation (Lafont et al., 2018). A similar study has shown that H-RN inhibits ocular inflammation in experimental autoimmune uveitis (EAU) by contributing to the attenuation of IKK complex activation and $\mathrm{I} \kappa \mathrm{B}$ degradation and significantly restraining the phosphorylation of NF-kB (Wang et al., 2014). More studies have been conducted to improve experimental uveitis by inhibiting the NF- $\kappa B$ signaling pathway, such as with lutein (Izumi-Nagai et al., 2007; Kijlstra et al., 2012), growth hormone (Liang et al., 2020), aminooxy-acetic acid (Meka et al., 2015; Mei et al., 2020), dehydroxymethylepoxyquinomicin (Ando et al., 2020), astaxanthin (Suzuki et al., 2006), silibinin (Chen et al., 2017), and aryl hydrocarbon receptor (Huang et al., 2018). Interestingly, a recent study showed that interleukin (IL)-17A inhibits the pathogenicity of Th17 cells by inducing the activation of IL-24 and the transcription factor NF- $\kappa B$ in EAU (Chong et al., 2020). However, clinical trials targeting IL-17A in uveitis have not been successful, which might be because the IL-17A-targeted drug improved EAU by inducing IL-24 in vivo, but silencing IL-24 in Th17 cells enhanced the disease. Some studies on inhibiting EAU by blocking the p38 signaling pathway, cannabidiol (El-Remessy et al., 2008), and IL-27 (Meka et al., 2015) have reported related results. These experiments have verified that the TNF- $\alpha$ signaling pathway is related to the pathogenesis of experimental uveitis, especially the NF- $\kappa \mathrm{B}$ pathways (Li S. et al., 2010). The regulation of various signaling components in the TNF- $\alpha$ signaling pathways also seems to be promising for controlling the progression of uveitis when there is a poor response to TNF- $\alpha$-agents. However, these ideas need to be verified with additional in vivo and in vitro experiments.

\section{Pathways Leading to Apoptosis and Necroptosis}

RIPK1, as a pivotal molecular switch, determines whether TNF- $\alpha$ signaling pathways result in cell apoptosis or necroptosis (Ea et al., 2006). RIPK1 is not ubiquitinated under the action of the deubiquitination enzyme cylindromatosis (CYLD) (Kovalenko et al., 2003; Komander et al., 2009) or the depletion of cIAPs (Bertrand et al., 2008), and it recruits different signaling molecules to form complex IIa and IIb, respectively. Following the assembly of complex II, pro-caspase 8 conducts autocatalytic cleavage, releasing active caspase 8 to trigger the implementation of the apoptotic program (Wang et al., 2008). When deubiquitylated RIPK1 exists but caspase is deactivated, RIPK1 and RIPK3 cannot be inactivated. Instead, they cluster together to form complex IIc (necrosome) and the necroptosis program is initiated (He et al., 2009; Li et al., 2012). The level of RIPK3 in cells is responsible for cell necroptosis rather than apoptosis (Vandenabeele et al., 2010). TNF- $\alpha$-induced cell necroptosis at various barrier surfaces impairs barrier function and leads to inflammation, such as retinal pigment epithelial (RPE) cells (Yumnamcha et al., 2019). However, it has been suggested that apoptosis and subsequent phagocytosis are of vital significance for the clearance of infiltrating cells from the eyes and the dissipation of EAU (Jha et al., 2007).

\section{KEY ROLE OF TUMOR NECROSIS FACTOR-ALPHA IN UNDERSTANDING UVEITIS}

In patients with active uveitis or uveitis animal models, TNF- $\alpha$ levels in serum and aqueous humor are elevated, which is correlated with disease status (Fleisher et al., 1991; Kaufmann et al., 2012). TNF- $\alpha$ results in uveitis after intravitreal injection into the rabbit eye (El-Asrar et al., 2011). Evidence suggests a marked association between TNF- $\alpha$ and uveitis. TNF- $\alpha$ induces the release of secondary cytokines, such as IL-6 (Sironi et al., 1989; Sugita et al., 2007) and IL-8 (Sancéau et al., 1990), as well as a monocyte chemotactic and activating factor (Larsen et al., 1989a), to initiate a cascade of events integral to the inflammatory process. TNF- $\alpha$ also induces the release of bioactive lipids, such as eicosanoids (Larsen et al., 1989b; Zavoico et al., 1989), and platelet-activating factor (Bussolino et al., 1986; Camussi et al., 1987; Meyer et al., 1990) and increases the expression of adhesion molecules on vascular endothelial cells (e.g., vascular cell adhesion molecule-1,VCAM-1) (Pober et al., 1986; Bevilacqua et al., 1987; Valone and Epstein, 1988; Carlos et al., 1990). Some investigators reported that TNF-a plays an important role in the upregulation of matrix metalloproteinases (MMPs) in RPE cells and accounts for a directional shift in the balance between MMPs and tissue inhibitors of MMPs (Iademarco et al., 1995; Eichler et al., 2002). Moreover, MMPs, as a type of enzyme that degrades the extracellular matrix, are closely related to the integrity of the blood-retinal barrier (BRB) in uveitis patients ( $\mathrm{Li} \mathrm{H}$. et al., 2010). T cells are important producers of TNF- $\alpha$, and TNF- $\alpha$ regulates T cell responses (Nussenblatt, 1991; Cope et al., 1997). Studies have shown that anti-TNF- $\alpha$ therapy suppresses the differentiation of T-helper type 17 cells (Th17) and prevents severe eye inflammation (Masters et al., 2009). In brief, TNF- $\alpha$, as a key link to intraocular inflammation, recruits leukocytes by mediating the production of intraocular chemokines, increases the adhesion of leukocytes to the vascular endothelium, enhances the antigen extraction ability of dendritic cells, activates macrophages and $\mathrm{T}$ cells, and eventually leads to the destruction of the BRB. The following part will summarize the previous research progress on the role of TNF- $\alpha$ in EAU in 
chronological order based on basic experiments, with emphasis on the aforementioned points.

\section{Progress on Tumor Necrosis Factor-Alpha in EAU}

EAU was first described in 1965 (Wacker and Lipton, 1965; Sugita et al., 2012). It can be induced by many autoantigens of intraocular cells. Animal models have identified retinal S-antigen/arrestin (S-Ag) (Caspi, 2011), interphotoreceptor retinoid-binding protein (IRBP) (Bieganowska et al., 1997), rhodopsin (de Smet et al., 1990), opsin (Yamamoto et al., 1993), phosducin (Gery et al., 1994), recoverin (Dua et al., 1992), Rpe65 (Nityanand et al., 1993), melanin (Nakamura et al., 2005), and lens proteins and cellular retinaldehydebinding protein (Broekhuyse et al., 1993) as "uveitogenic". Now, EAU is generally used as experimental models of uveitis to study the immunopathologic mechanisms of human intraocular inflammatory diseases. Many studies have observed a constant increase in TNF- $\alpha$ expression in inflammatory cell infiltrates, not only in various models of experimental uveitis, but also in RPE and Müller cells, which causes these cells to possess uveitogenic properties and might decisively influence the course of EAU (de Kozak et al., 1997; de Smet and Chan, 2001; Holtkamp et al., 2001).

\section{Tumor Necrosis Factor-Alpha and TNF- $\alpha$ Blockade in Different Animal Experimental Models}

In 1993, a team observed that TNF- $\alpha$ could protect against the inflammatory processes of endotoxin-induced uveitis (EIU) (Huang et al., 2018). By contrast, Nakamura et al. reported that the injection of recombinant huTNF in mouse models increases susceptibility to EAU (Kasner et al., 1993). One experiment demonstrated that mice deficient in TNFR retain their susceptibility to EIU (Nakamura et al., 1994). However, another study indicated that mice with TNF receptor deficiency show decreased inflammation in an immune complex model of uveitis (Smith et al., 1998). In 1997, a study confirmed that TNF- $\alpha$ is not essential for inducing experimental autoimmune diseases (Brito et al., 1999), and a chronic low level of TNF-a might exert protective effects.

In 1996, a study showed that the neutralization of systemic TNF- $\alpha$ ameliorates the pathology of EAU, and interference with afferent processes, especially antigen priming, is important to protect against EAU through anti-TNF- $\alpha$ treatment (Frei et al., 1997). A similar result was observed in a 2001 study, in which IRBP-induced EAU in mice with a TNFR1-Ig fusion protein reduces damage to the retina (Sartani et al., 1996). However, TNF- $\alpha$ neutralization is ultimately not curative in experimental models of relapsing disease (Hankey et al., 2001). In 2003, Baker et al. (1994) identified that etanercept (an anti-TNF- $\alpha$ agent) decreases leukocyte rolling, leukocyte adhesion, and vascular leakage in a rat model of EIU. This outcome suggested that TNF- $\alpha$ is involved in the pathogenesis of uveitis and its potential use as a therapeutic drug to reduce ocular inflammation. In 2019, a study showed that intravitreal infliximab injection exacerbates inflammation in EIU models, whereas systemic infliximab treatment suppresses inflammation effectively and rapidly (Koizumi et al., 2003). It can be seen that the results of both TNF- $\alpha$ and TNF- $\alpha$ blocking experiments are inconsistent in different animal models. These opposite conclusions might be dependent on the experimental model, EAU or EIU. Moreover, these contradictory findings could suggest the different responses of patients with uveitis to certain therapies because of the diversity of uveitis pathogenesis.

\section{Adhesion Molecule Regulation and BRB Rupture}

In 1990, some investigators showed that TNF- $\alpha$ antagonists prevent adhesion molecule upregulation on the vascular endothelial cells in rheumatoid arthritis (RA) and experimental allergic encephalomyelitis (Ruddle et al., 1990; Liversidge et al., 2000). In 2011, investigators found that TNFa expression decreases in aldehyde reductase-deficient mice, downregulating VCAM-1 expression (Elliott et al., 1994). In 2014, a study demonstrated that H-RN, a novel antiangiogenic peptide derived from hepatocyte growth factor which is an important angiogenic factor in vascular retinopathies, suppresses TNF- $\alpha$-induced adhesion molecule expression (such as VCAM-1) in EAU (Wang et al., 2014). Further, silibinin was shown to prevent EIU and the subsequent production of ICAM-1 by blocking the NF- $\mathrm{kB}$-dependent signaling pathway in 2017 (Chen et al., 2017).

In 1997, a study showed that TNF- $\alpha$ causes BRB rupture by opening tight junctions between retinal vascular endothelial cells and possibly by increasing transdermal vesicle transport in EAU (Yadav et al., 2011). In 2010, a team reported that TNF- $\alpha$ downregulates AQP1 protein expression in the retina, resulting in BRB breakdown (Luna et al., 1997). In 2017, chrysin (5,7-dihydroxyflavone) was reported to maintain the integrity of the $\mathrm{BRB}$ via suppression of the expression of inducible nitric oxide synthase (NOS) and macrophage infiltration in the retina, significantly decreasing the percentage of Th17 cells and $\mathrm{CD}^{+}$cells, increasing the percentage of Treg cells, and suppressing ocular inflammation during EAU (Motulsky et al., 2010). In 2018, a report indicated that aryl hydrocarbon receptor-knockout mice show a decrease in pro-inflammatory cytokines, such as TNF- $\alpha$, thereby inhibiting retinal cell apoptosis and reducing $\mathrm{BRB}$ decomposition during EAU (Meng et al., 2017).

\section{Effects of Tumor Necrosis Factor-Alpha on Macrophage and Th17 Activity}

In 1998, Dick et al. observed that the inhibition of TNF- $\alpha$ activity protects against organ destruction without suppressing retinal $\mathrm{T}$ cell infiltration during EAU in Lewis rats. To demonstrate whether neutralizing TNF activity leads to a change in macrophage activation, some trials have used TNFR1, resulting in reduced nitrite in macrophages infiltrating the retina of the treated animal, thereby reducing target tissue damage and destruction (Dick et al., 1998). In these experiments, NOS2 inhibition induced by a nonspecific inhibitor of NOS resulted in a reduction in EAU (Robertson et al., 2003). The role of TNF- $\alpha$ in macrophages was also demonstrated in a 2009 study, which reported that high 
mobility group box 1 protein can stimulate TNF- $\alpha$ production in macrophages to promote and amplify ocular inflammation in EAU (Liversidge et al., 2002).

In 2007, Amadi et al. first described Th17 cells in EAU. They confirmed that IL-17 is increased in EAU, regulating TNF- $\alpha$ in retinal cells, suggesting a mechanism in which Th17 might contribute to ocular immunopathology (Watanabe et al., 2009). In 2019, a team reported that although TIPE2-deficient (TIPE2, one member of TNF- $\alpha$-induced protein) $\mathrm{T}$ cells produce more IL-17, they do not migrate to the skin as efficiently. Instead, they migrate to the inflamed eye in a similar manner to TIPE2deficient $\mathrm{T}$ cells and thus exacerbate the development of EAU in TIPE2-deficient mice but reduce the severity of psoriasis in these animals (Amadi-Obi et al., 2007).

\section{TUMOR NECROSIS FACTOR-ALPHA AS A THERAPEUTIC TARGET FOR UVEITIS}

Systemic immunomodulatory therapy (IMT) has been used to treat specific patients with uveitis over the last decades. Corticosteroids are an important component of IMT and are also the first-line treatment for uveitis. However, patients with uveitis are at risk of long-term complications caused by long-term uncontrolled inflammation and corticosteroid therapy, which can reduce the treatment success rate for the disease itself. Therapeutic strategies have evolved over the last few years, and anti-TNF- $\alpha$ agents have become well accepted for the treatment of refractory uveitis. Anti-TNF- $\alpha$ agents have fewer adverse effects than corticosteroids. Studies have shown that when used properly, dependence on corticosteroids can be significantly reduced to prevent uveitis recurrence (Liu et al., 2019).

\section{Development of anti-TNF-a Agents in Uveitis}

The first use of anti-TNF- $\alpha$ agents was reported in the 1980s in experimental models of sepsis (Beutler et al., 1985; Tracey et al., 1987; Calandra et al., 1991; Hu et al., 2020). In 1985, Feldmann et al. identified TNF- $\alpha$ as a therapeutic target for RA and reported the first proof of concept trials (Feldmann and Maini, 2003). In 1991, Keffer et al. reported the effectiveness of anti-TNF-a therapy for arthritis (Keffer et al., 1991). The success of phase I/II trials of anti-TNF- $\alpha$ antibodies announced in 1992 contributed to the performance of clinical trials for other chronic diseases. Since the first reported use of infliximab in 2001 for uveitis treatment, several new anti-TNF- $\alpha$ agents have been developed for the treatment of refractory uveitis (MuñozFernández et al., 2001; Sfikakis et al., 2001). Four monoclonal anti-TNF- $\alpha$ antibodies, namely, infliximab (IFX; Remicade ${ }^{\circledR}$ ), adalimumab (ADA; Humira ${ }^{\circledR}$ ), golimumab (GOL; Simponi ${ }^{\circledR}$ ), and certolizumab pegol (CZP; Cimzia ${ }^{\circledR}$ ), are available. Etanercept (Enbrel $\left.{ }^{\circledR}\right)$ is the only commercially available receptor fusion protein (Sandborn et al., 2001). In 2011, Cordero-Coma et al. first reported two cases of treatment with GOL, which both achieved satisfactory results (Tracey et al., 2008; Cordero-
Coma et al., 2011). In 2016, the United States Food and Drug Administration (FDA) approved ADA as the first anti-TNF- $\alpha$ agent for the treatment of non-infectious intermediate, posterior, and panuveitis (Hasegawa et al., 2019). In the same year, clinical trials were performed on the effectiveness of CZP for refractory spondyloarthritis-related uveitis, but no significant advantages were found over other anti-TNF- $\alpha$ agents (Rudwaleit et al., 2016). Different inhibitors have different functional profiles. IFX, ADA, and GOL are humanized monoclonal antibodies, whereas CZP is a monovalent fragment linked to polyethylene glycol. ADA and GOL are fully human monoclonal antibodies; however, IFX is a chimeric protein with both human and murine components. The lack of the fragment crystallizable $(\mathrm{Fc})$ portion suppresses the high immunogenicity of CZP and makes it less likely to cross the placenta in pregnant patients. Etanercept is a recombinant fusion protein composed of the extracellular portions of TNFR2 combined with the Fc portion of human immunoglobulin G-1. The most frequent side effect was determined to be infusion reaction, with infectious diseases including tuberculosis being second most common; the occurrence of demyelinating or autoimmune diseases was seldom reported. The associated risk of cancer has been debated. To date, anti-TNF- $\alpha$ agents have made more progress for uveitis treatment. The different characteristics of anti-TNF- $\alpha$ agents derived from clinical trials are summarized as below (summarized in Supplementary Table S1).

\section{ADA (Humira ${ }^{\circledR}$ )}

The advantages of ADA are listed as follows:

1) Compared with IFX, ADA is a fully human monoclonal antibody that causes almost no allergic reactions, and subcutaneous injection is safer and more convenient than intravenous injection (Ming et al., 2018).

2) During steroid tapering, $\mathrm{ADA}$ significantly reduces the relapse rate, visual deterioration, and anterior chamber flare, and has relatively good tolerance (Díaz-Llopis et al., 2012; Jaffe et al., 2016).

3) The use of ADA in the treatment of uveitis associated with Behçet's disease (BD) is not affected by the concomitant application of antirheumatic agents (Nguyen et al., 2016; Fabiani et al., 2018).

4) Numerous studies have shown that $\mathrm{ADA}$ is superior to immunosuppressive agents in decreasing the relapse rate and occurrence of retinal vasculitis and improving visual acuity (Sota et al., 2021).

5) $\mathrm{ADA}$ is safe and efficacious for the treatment of noninfectious uveitis in elderly patients (Moll-Udina et al., 2020).

6) $\mathrm{ADA}$ seems to be associated with better outcomes after followup, although both IFX and ADA are efficacious for refractory BD-related uveitis (Atienza-Mateo et al., 2019).

7) $\mathrm{ADA}$ plus conventional therapy outperforms conventional therapy alone in patients with retinal vasculitis due to refractory BD-related uveitis (Yang et al., 2021a; Yang et al., 2021b).

8) In children and adolescents with active juvenile idiopathic arthritis (JIA)-related uveitis, the treatment failure rate of 
ADA is lower than that of the placebo (Ramanan et al., 2017; Angeles-Han et al., 2019).

The disadvantages of ADA are as follows:

1) Adverse events were reported in patients who received ADA (Díaz-Llopis et al., 2012). The most frequently reported treatmentemergent adverse event is infection (Al-Janabi et al., 2020).

2) The use of ADA for undifferentiated uveitis might result in premature discontinuation on account of side effects (Al-Janabi et al., 2020; Llorenç et al., 2020).

The indications are as follows:

1) Non-infectious uveitis, intermediate uveitis, posterior uveitis, and panuveitis in adult patients with underreaction and contraindications to steroids, as well as steroid dependence in Europe (Leclercq et al., 2020).

2) Non-infectious uveitis, intermediate uveitis, posterior uveitis, and panuveitis in adult patients in the United States (Leclercq et al., 2020).

3) As a first-line immunomodulator for the treatment of ophthalmic manifestations of BD (Touhami et al., 2019).

4) As a second-line immunomodulator for the treatment of uveitis associated with JIA (Angeles-Han et al., 2019; Llorenç et al., 2020).

5) $\mathrm{ADA}$ is approved for RA, ulcerative colitis, psoriatic arthritis, ankylosing spondylitis (AS), Crohn's disease, and plaque psoriasis in adults (Llorenç et al., 2020).

\section{IFX (Remicade ${ }^{\circledR}$ )}

The advantages of IFX are listed as follows:

1) IFX showed commendable efficacy for refractory non-infectious uveitis and severe uveitis cases associated with BD whether it was used as monotherapy or with other immunosuppressive agents (Vallet et al., 2015; Vallet et al., 2016).

2) IFX showed a significantly higher capacity to resolve macular edema in treating sight-threatening retinal vasculitis when compared with the effects of ADA (Levy-Clarke et al., 2014).

3) A report indicated that IFX is effective as a treatment for visually threatening refractory posterior uveitis (Joseph et al., 2003).

4) Multiple studies have shown that IFX is superior to immunosuppressive agents in reducing recurrence rates and ameliorating visual acuity (Vallet et al., 2015).

5) Arida et al. reported that $40 \%$ of $\mathrm{BD}$ cases remained in remission 3 years after the discontinuation of IFX (Vallet et al., 2015). In the event of relapse, good response rates were obtained after the resumption of IFX therapy (Markomichelakis et al., 2011).

The disadvantages of the IFX are listed as follows:

1) Tolerance is low owing to the relatively frequent infusion reactions (Lichtenstein et al., 2015; Leclercq et al., 2020).
2) Tuberculosis as an adverse effect was reported in patients treated with IFX (Tugal-Tutkun et al., 2005).

3) One study reported a higher rate of IFX toxicity in patients with uveitis (Markomichelakis et al., 2011).

The indications are as follows:

1) Numerous experts have recommended IFX as first-line therapy for visually threatening $\mathrm{BD}$ (macular ischemia, cystoid macular edema, serious vasculitis, monophthalmic patients) (Arida et al., 2011; Hatemi et al., 2018).

2) As a second-line immunomodulator for the treatment of uveitis related to JIA (Angeles-Han et al., 2019).

3) For the treatment of severe ocular inflammatory conditions including posterior uveitis, panuveitis, severe uveitis associated with seronegative spondyloarthropathy, and scleritis in patients requiring immunomodulation (LevyClarke et al., 2014).

4) Infliximab is authorized by the FDA for the treatment of RA, AS, Crohn's disease, psoriatic arthritis, plaque psoriasis in adults, and ulcerative colitis (Sobrin et al., 2007; Arida et al., 2011).

\section{GOL (Simponi ${ }^{\circledR}$ )}

The advantages of the GOL are listed as follows:

1) Compared with IFX, GOL is a fully human monoclonal antibody that causes almost no allergic reactions (Ming et al., 2018).

2) GOL is effective in improving visual acuity and controlling ocular inflammation (Cordero-Coma et al., 2014).

3) GOL has been proven to be conducive to AS-related anterior uveitis, ameliorating macular edema and inflammation, and decreasing the relapse rate (Calvo-Río et al., 2016; Fabiani et al., 2016).

4) The control of intraocular inflammation with multi-refractory uveitis associated with BD (Hatemi et al., 2018).

5) GOL represents an efficacious and secure therapy choice for uveitis with a significant reduction in the frequency of ocular flares while preserving visual function with a satisfactory longterm retention rate (Fabiani et al., 2019).

6) The effective treatment of JIA and idiopathic retinal vasculitis by GOL has been reported, whereas other anti-TNF- $\alpha$ agents are ineffective (Tosi et al., 2019).

\section{CZP (Cimzia ${ }^{\circledR}$ )}

The advantages of the CZP are listed as follows:

1) CZP can be an effective alternative to long-lasting chronic relapsing uveitis (Llorenç et al., 2016).

2) Some studies have shown a significant decrease in ocular flares with a satisfactory long-term retention rate with CZP compared to that with placebo (Tosi et al., 2019).

3) A national multicenter observational study supported the efficacy of CZP for the management of uveitis during pregnancy (Prieto-Peña et al., 2021). In terms of pregnancy safety, CZP displayed advantageous properties over other 
anti-TNF- $\alpha$ agents because of its limited transport across the placenta (Mariette et al., 2018).

4) One study showed that the relative in vitro neutralizing potency is higher for CZP than for ADA (Berkhout et al., 2020).

5) One study observed positive outcomes using CZP as therapy for patients with refractory, non-infectious uveitis when other anti-TNF- $\alpha$ agents proved inadequate or when tolerance issues were present (Sharon and Chu, 2020).

\section{Etanercept (Enbrel $\left.{ }^{\circledR}\right)$}

The disadvantages of etanercept are listed as follows:

1) Owing to its poor intraocular permeability and limited effectiveness, it is not recommended for uveitis (Dick et al., 2018).

2) Granulomatosis, as a side effect, has been reported in the treatment of uveitis with etanercept (Leal et al., 2019).

3) Meta-analyses have shown that etanercept is inferior to other anti-TNF- $\alpha$ agents for uveitis treatment (Leal et al., 2019).

4) Paradoxical occurrences of uveitis have also been reported after etanercept administration in patients with AS-related acute anterior uveitis (Fabiani et al., 2016).

5) Etanercept might be less efficient than other anti-TNF- $\alpha$ agents in decreasing the risk of HLA-B27-related acute anterior uveitis in patients with spondyloarthritis (Mitulescu et al., 2018).

The indications are as follows:

1) Etanercept received FDA approval for RA, polyarticular JIA, AS, psoriatic arthritis, and plaque psoriasis (in patients aged 17 years and older) (Fabiani et al., 2016).

2) International guidelines concluded that the use of etanercept for the treatment of uveitis is not supported (Dick et al., 2018).

\section{CONCLUSION}

Inefficiently controlled or untreated uveitis is one of the primary causes of blindness in developed countries. Corticosteroids remain the first-line treatment; however, their chronic use can result in side effects. These complications have led investigators to seek corticosteroid-sparing treatments. Although uveitis represents a group of intraocular inflammatory conditions with distinct phenotypic heterogeneity, its common feature is increased expression of TNF- $\alpha$ in both the serum and aqueous humor. Over the past decade, studies have increasingly emphasized the effectiveness of anti-TNF- $\alpha$ agents for patients with uveitis. However, the lack of clinical trials and the rarity and heterogeneity of uveitis make their utilization in ophthalmology more challenging, particularly for first-line therapy.

Most international studies have focused on ADA and IFX, which are the most commonly recently employed biological agents for patients with uveitis. Authoritative experts recommended the use of ADA in cases of nullity or intolerance to immunosuppressive agents for non-infectious non-anterior uveitis. IFX was proposed as a first-line treatment for sight-threatening uveitis associated with BD.
Nevertheless, knowing which of the two has a better effect in combating uveitis is an unmet demand. ADA is well tolerated with acceptable side effect profiles, and its costs have also decreased to acceptable levels. These properties make it an excellent option as second-line and reserved steroid therapy for uveitis. However, whether the earlier introduction of ADA would confer additional benefits in the management of uveitis and the preservation of visual function is unclear. GOL seems to have more evident advantages as a therapy for spondylitis-related uveitis. In terms of pregnancy safety, CZP has favorable characteristics over other anti-TNF- $\alpha$ agents owing to its limited transport across the placenta.

Furthermore, there are still many questions regarding the use of anti-TNF- $\alpha$ agents as a therapy for uveitis, including the following: treatment duration, when to stop using, the necessity to monitor drug levels regularly, alternative biological agents if anti-TNF- $\alpha$ failure occurs, how to reduce the immunogenicity against anti-TNF- $\alpha$ molecules, and how to ameliorate efficacy. Moreover, treatment failure when using one anti-TNF- $\alpha$ agent does not indicate that other agents in the same group will also be ineffective. Some studies have reported that agents in a group can be replaced with each other by changing novel routes of drug administration to less intense places such as subcutaneous injections. The development of monoclonal antibodies that simultaneously recognize multiple targets allows for more effective treatment of uveitis at a lower dose than that with any single biological drug. Alternatively, a secure and efficient sustained-release device can be developed that will enable the topical treatment of idiopathic immunemediated uveitis with immunomodulators, including biological response modifiers. The pathogenic effect of TNF- $\alpha$ is caused by complex signaling pathways composed of cascades of signaling molecules. When the efficacy of anti-TNF- $\alpha$ agents is not good, changing therapeutic targets to different signaling molecules in the pathway is also a good alternative. However, these ideas need to be verified with additional in vivo and in vitro experiments.

\section{AUTHOR CONTRIBUTIONS}

Conception and design: WS; Drafting and revising of the article: WS, XW, QJ, ZL, RD, and TT; Final approval: WS.

\section{FUNDING}

This study was supported by the National Key Research and Development Program of China (2017YFA0105804).

\section{SUPPLEMENTARY MATERIAL}

The Supplementary Material for this article can be found online at: https://www.frontiersin.org/articles/10.3389/fphar.2021.740057/ full\#supplementary-material 


\section{REFERENCES}

Aggarwal, B. B., Gupta, S. C., and Kim, J. H. (2012). Historical Perspectives on Tumor Necrosis Factor and its Superfamily: 25 Years Later, a Golden Journey. Blood. 119 (3), 651-665. doi:10.1182/blood-2011-04-325225

Aggarwal, B. B., Kohr, W. J., Hass, P. E., Moffat, B., Spencer, S. A., Henzel, W. J., et al. (1985). Human Tumor Necrosis Factor. Production, Purification, and Characterization. J. Biol. Chem. 260 (4), 2345-2354. doi:10.1016/s00219258(18)89560-6

Al-Janabi, A., El Nokrashy, A., Sharief, L., Nagendran, V., Lightman, S., and Tomkins-Netzer, O. (2020). Long-Term Outcomes of Treatment With Biological Agents in Eyes With Refractory, Active, Noninfectious Intermediate Uveitis, Posterior Uveitis, or Panuveitis. Ophthalmology. 127 (3), 410-416. doi:10.1016/j.ophtha.2019.08.031

Amadi-Obi, A., Yu, C. R., Liu, X., Mahdi, R. M., Clarke, G. L., Nussenblatt, R. B., et al. (2007). TH17 Cells Contribute to Uveitis and Scleritis and Are Expanded by IL-2 and Inhibited by IL-27/STAT1. Nat. Med. 13 (6), 711-718. doi:10.1038/nm1585

Ando, Y., Keino, H., Kudo, A., Hirakata, A., Okada, A. A., and Umezawa, K. (2020). Anti-Inflammatory Effect of Dehydroxymethylepoxyquinomicin, a Nuclear Factor-Kb Inhibitor, on Endotoxin-Induced Uveitis in Rats In Vivo and In Vitro. Ocul. Immunol. Inflamm. 28 (2), 240-248. doi:10.1080/ 09273948.2019.1568502

Angeles-Han, S. T., Ringold, S., Beukelman, T., Lovell, D., Cuello, C. A., Becker, M. L., et al. (2019). 2019 American College of Rheumatology/Arthritis Foundation Guideline for the Screening, Monitoring, and Treatment of Juvenile Idiopathic Arthritis-Associated Uveitis. Arthritis Rheumatol. 71 (6), 864-877. doi:10.1002/ art.40885

Arida, A., Fragiadaki, K., Giavri, E., and Sfikakis, P. P. (2011). Anti-TNF Agents for Behçet's Disease: Analysis of Published Data on 369 Patients. Semin. Arthritis Rheum. 41 (1), 61-70. doi:10.1016/j.semarthrit.2010.09.002

Atienza-Mateo, B., Martín-Varillas, J. L., Calvo-Río, V., Demetrio-Pablo, R., Beltrán, E., Sánchez-Bursón, J., et al. (2019). Comparative Study of Infliximab Versus Adalimumab in Refractory Uveitis Due to Behçet's Disease: National Multicenter Study of 177 Cases. Arthritis Rheumatol. 71 (12), 2081-2089. doi:10.1002/art.41026

Bajwa, A., Osmanzada, D., Osmanzada, S., Khan, I., Patrie, J., Xin, W., et al. (2015). Epidemiology of Uveitis in the Mid-Atlantic United States. Clin. Ophthalmol. 9, 889-901. doi:10.2147/opth.S80972

Baker, D., Butler, D., Scallon, B. J., O’Neill, J. K., Turk, J. L., and Feldmann, M. (1994). Control of Established Experimental Allergic Encephalomyelitis by Inhibition of Tumor Necrosis Factor (TNF) Activity Within the central Nervous System Using Monoclonal Antibodies and TNF ReceptorImmunoglobulin Fusion Proteins. Eur. J. Immunol. 24 (9), 2040-2048. doi:10.1002/eji.1830240916

Barisani-Asenbauer, T., Maca, S. M., Mejdoubi, L., Emminger, W., Machold, K., and Auer, H. (2012). Uveitis- a Rare Disease Often Associated With Systemic Diseases and Infections- a Systematic Review of 2619 Patients. Orphanet J. Rare Dis. 7, 57. doi:10.1186/1750-1172-7-57

Berkhout, L. C., Vogelzang, E. H., Hart, M. M., Loeff, F. C., Dijk, L., Derksen, N. I. L., et al. (2020). The Effect of Certolizumab Drug Concentration and Anti-Drug Antibodies on TNF Neutralisation. Clin. Exp. Rheumatol. 38 (2), 306-313.

Bertrand, M. J., Milutinovic, S., Dickson, K. M., Ho, W. C., Boudreault, A., Durkin, J., et al. (2008). cIAP1 and cIAP2 Facilitate Cancer Cell Survival by Functioning as E3 Ligases that Promote RIP1 Ubiquitination. Mol. Cell. 30 (6), 689-700. doi:10.1016/j.molcel.2008.05.014

Beutler, B., Milsark, I. W., and Cerami, A. C. (1985). Passive Immunization against Cachectin/Tumor Necrosis Factor Protects Mice from Lethal Effect of Endotoxin. Science. 229 (4716), 869-871. doi:10.1126/science.3895437

Bevilacqua, M. P., Pober, J. S., Mendrick, D. L., Cotran, R. S., and Gimbrone, M. A., Jr. (1987). Identification of an Inducible Endothelial-Leukocyte Adhesion Molecule. Proc. Natl. Acad. Sci. U S A. 84 (24), 9238-9242. doi:10.1073/ pnas.84.24.9238

Bieganowska, K. D., Ausubel, L. J., Modabber, Y., Slovik, E., Messersmith, W., and Hafler, D. A. (1997). Direct Ex Vivo Analysis of Activated, Fas-Sensitive Autoreactive T Cells in Human Autoimmune Disease. J. Exp. Med. 185 (9), 1585-1594. doi:10.1084/jem.185.9.1585
Black, R. A., Rauch, C. T., Kozlosky, C. J., Peschon, J. J., Slack, J. L., Wolfson, M. F., et al. (1997). A Metalloproteinase Disintegrin That Releases Tumour-Necrosis Factor-Alpha From Cells. Nature. 385 (6618), 729-733. doi:10.1038/385729a0

Bodaghi, B., Cassoux, N., Wechsler, B., Hannouche, D., Fardeau, C., Papo, T., et al. (2001). Chronic Severe Uveitis: Etiology and Visual Outcome in 927 Patients From a Single center. Medicine (Baltimore). 80 (4), 263-270. doi:10.1097/ 00005792-200107000-00005

Brenner, D., Blaser, H., and Mak, T. W. (2015). Regulation of Tumour Necrosis Factor Signalling: Live or let die. Nat. Rev. Immunol. 15 (6), 362-374. doi:10.1038/nri3834

Brito, B. E., O’Rourke, L. M., Pan, Y., Anglin, J., Planck, S. R., and Rosenbaum, J. T. (1999). IL-1 and TNF Receptor-Deficient Mice Show Decreased Inflammation in an Immune Complex Model of Uveitis. Invest. Ophthalmol. Vis. Sci. 40 (11), 2583-2589.

Broekhuyse, R. M., Kuhlmann, E. D., and Winkens, H. J. (1993). Experimental Autoimmune Anterior Uveitis (EAAU): Induction by Melanin Antigen and Suppression by Various Treatments. Pigment Cell Res. 6 (1), 1-6. doi:10.1111/ j.1600-0749.1993.tb00574.x

Bussolino, F., Breviario, F., Tetta, C., Aglietta, M., Sanavio, F., Mantovani, A., et al. (1986). Interleukin 1 Stimulates Platelet Activating Factor Production in Cultured Human Endothelial Cells. Pharmacol. Res. Commun. 18 Suppl (Suppl. 1), 133-137. doi:10.1016/0031-6989(86)90046-9

Bystrom, J., Clanchy, F. I., Taher, T. E., Mangat, P., Jawad, A. S., Williams, R. O., et al. (2018). TNFa in the Regulation of Treg and Th17 Cells in Rheumatoid Arthritis and Other Autoimmune Inflammatory Diseases. Cytokine. 101, 4-13. doi:10.1016/j.cyto.2016.09.001

Calandra, T., Baumgartner, J. D., and Glauser, M. P. (1991). AntiLipopolysaccharide and Anti-Tumor Necrosis Factor/Cachectin Antibodies for the Treatment of Gram-Negative Bacteremia and Septic Shock. Prog. Clin. Biol. Res. 367, 141-159.

Calvo-Río, V., Blanco, R., Santos-Gómez, M., Rubio-Romero, E., Cordero-Coma, M., Gallego-Flores, A., et al. (2016). Golimumab in Refractory Uveitis Related to Spondyloarthritis. Multicenter Study of 15 Patients. Semin. Arthritis Rheum. 46 (1), 95-101. doi:10.1016/j.semarthrit.2016.03.002

Camussi, G., Bussolino, F., Salvidio, G., and Baglioni, C. (1987). Tumor Necrosis Factor/cachectin Stimulates Peritoneal Macrophages, Polymorphonuclear Neutrophils, and Vascular Endothelial Cells to Synthesize and Release Platelet-Activating Factor. J. Exp. Med. 166 (5), 1390-1404. doi:10.1084/ jem.166.5.1390

Carlos, T. M., Schwartz, B. R., Kovach, N. L., Yee, E., Rosa, M., Osborn, L., et al. (1990). Vascular Cell Adhesion Molecule-1 Mediates Lymphocyte Adherence to Cytokine-Activated Cultured Human Endothelial Cells. Blood. 76 (5), 965-970. doi:10.1182/blood.v76.5.965.bloodjournal765965

Caspi, R. R. (2011). Understanding Autoimmune Uveitis Through Animal Models. The Friedenwald Lecture. Invest. Ophthalmol. Vis. Sci. 52 (3), 1872-1879. doi:10.1167/iovs.10-6909

Chen, C. L., Chen, J. T., Liang, C. M., Tai, M. C., Lu, D. W., and Chen, Y. H. (2017). Silibinin Treatment Prevents Endotoxin-Induced Uveitis in Rats In Vivo and In Vitro. PLoS One. 12 (4), e0174971. doi:10.1371/journal.pone.0174971

Chong, W. P., Mattapallil, M. J., Raychaudhuri, K., Bing, S. J., Wu, S., Zhong, Y., et al. (2020). The Cytokine IL-17A Limits Th17 Pathogenicity via a Negative Feedback Loop Driven by Autocrine Induction of IL-24. Immunity. 53 (2), 384-e5. e385. doi:10.1016/j.immuni.2020.06.022

Cope, A. P., Liblau, R. S., Yang, X. D., Congia, M., Laudanna, C., Schreiber, R. D., et al. (1997). Chronic Tumor Necrosis Factor Alters T Cell Responses by Attenuating T Cell Receptor Signaling. J. Exp. Med. 185 (9), 1573-1584. doi:10.1084/jem.185.9.1573

Cordero-Coma, M., Calvo-Río, V., Adán, A., Blanco, R., Álvarez-Castro, C., Mesquida, M., et al. (2014). Golimumab as rescue Therapy for Refractory Immune-Mediated Uveitis: a Three-Center Experience. Mediators Inflamm. 2014, 717598. doi:10.1155/2014/717598

Cordero-Coma, M., Salom, D., Díaz-Llopis, M., López-Prats, M. J., and Calleja, S. (2011). Golimumab for Uveitis. Ophthalmology. 118 (9), 1892e1893-4. doi:10.1016/j.ophtha.2011.05.019

de Kozak, Y., Cotinet, A., Goureau, O., Hicks, D., and Thillaye-Goldenberg, B. (1997). Tumor Necrosis Factor and Nitric Oxide Production by Resident 
Retinal Glial Cells From Rats Presenting Hereditary Retinal Degeneration. Ocul. Immunol. Inflamm. 5 (2), 85-94. doi:10.3109/09273949709085056

de Smet, M. D., and Chan, C. C. (2001). Regulation of Ocular Inflammation-What Experimental and Human Studies Have Taught Us. Prog. Retin. Eye Res. 20 (6), 761-797. doi:10.1016/s1350-9462(01)00011-8

de Smet, M. D., Yamamoto, J. H., Mochizuki, M., Gery, I., Singh, V. K., Shinohara, T., et al. (1990). Cellular Immune Responses of Patients With Uveitis to Retinal Antigens and Their Fragments. Am. J. Ophthalmol. 110 (2), 135-142. doi:10.1016/s0002-9394(14)76981-8

Díaz-Llopis, M., Salom, D., Garcia-de-Vicuña, C., Cordero-Coma, M., Ortega, G., Ortego, N., et al. (2012). Treatment of Refractory Uveitis With Adalimumab: a Prospective Multicenter Study of 131 Patients. Ophthalmology. 119 (8), 1575-1581. doi:10.1016/j.ophtha.2012.02.018

Dick, A. D., Duncan, L., Hale, G., Waldmann, H., and Isaacs, J. (1998). Neutralizing TNF-Alpha Activity Modulates T-Cell Phenotype and Function in Experimental Autoimmune Uveoretinitis. J. Autoimmun. 11 (3), 255-264. doi:10.1006/jaut.1998.0197

Dick, A. D., Rosenbaum, J. T., Al-Dhibi, H. A., Belfort, R., Jr., Brézin, A. P., Chee, S. P., et al. (2018). Guidance on Noncorticosteroid Systemic Immunomodulatory Therapy in Noninfectious Uveitis: Fundamentals of Care for UveitiS (FOCUS) Initiative. Ophthalmology. 125 (5), 757-773. doi:10.1016/j.ophtha.2017.11.017

Dick, A. D., Tundia, N., Sorg, R., Zhao, C., Chao, J., Joshi, A., et al. (2016). Risk of Ocular Complications in Patients With Noninfectious Intermediate Uveitis, Posterior Uveitis, or Panuveitis. Ophthalmology. 123 (3), 655-662. doi:10.1016/ j.ophtha.2015.10.028

Dua, H. S., Lee, R. H., Lolley, R. N., Barrett, J. A., Abrams, M., Forrester, J. V., et al. (1992). Induction of Experimental Autoimmune Uveitis by the Retinal Photoreceptor Cell Protein, Phosducin. Curr. Eye Res. 11 Suppl (Suppl. 1), 107-111. doi:10.3109/02713689208999519

Ea, C. K., Deng, L., Xia, Z. P., Pineda, G., and Chen, Z. J. (2006). Activation of IKK by TNFalpha Requires Site-Specific Ubiquitination of RIP1 and Polyubiquitin Binding by NEMO. Mol. Cell. 22 (2), 245-257. doi:10.1016/j.molcel.2006.03.026

Eichler, W., Friedrichs, U., Thies, A., Tratz, C., and Wiedemann, P. (2002). Modulation of Matrix Metalloproteinase and TIMP-1 Expression by Cytokines in Human RPE Cells. Invest. Ophthalmol. Vis. Sci. 43 (8), 2767-2773.

El-Asrar, A. M., Struyf, S., Kangave, D., Al-Obeidan, S. S., Opdenakker, G., Geboes, K., et al. (2011). Cytokine Profiles in Aqueous Humor of Patients With Different Clinical Entities of Endogenous Uveitis. Clin. Immunol. 139 (2), 177-184. doi:10.1016/j.clim.2011.01.014

El-Remessy, A. B., Tang, Y., Zhu, G., Matragoon, S., Khalifa, Y., Liu, E. K., et al. (2008). Neuroprotective Effects of Cannabidiol in Endotoxin-Induced Uveitis: Critical Role of P38 MAPK Activation. Mol. Vis. 14, 2190-2203.

Elliott, M. J., Maini, R. N., Feldmann, M., Kalden, J. R., Antoni, C., Smolen, J. S., et al. (1994). Randomised Double-Blind Comparison of Chimeric Monoclonal Antibody to Tumour Necrosis Factor Alpha (cA2) Versus Placebo in Rheumatoid Arthritis. Lancet. 344 (8930), 1105-1110. doi:10.1016/s01406736(94)90628-9

Fabiani, C., Sota, J., Rigante, D., Vitale, A., Emmi, G., Vannozzi, L., et al. (2019). Rapid and Sustained Efficacy of Golimumab in the Treatment of Multirefractory Uveitis Associated with Behçet's Disease. Ocul. Immunol. Inflamm. 27 (1), 58-63. doi:10.1080/09273948.2017.1351573

Fabiani, C., Sota, J., Vitale, A., Rigante, D., Emmi, G., Vannozzi, L., et al. (2018). Cumulative Retention Rate of Adalimumab in Patients With Behçet's DiseaseRelated Uveitis: a Four-Year Follow-Up Study. Br. J. Ophthalmol. 102 (5), 637-641. doi:10.1136/bjophthalmol-2017-310733

Fabiani, C., Vitale, A., Lopalco, G., Iannone, F., Frediani, B., and Cantarini, L. (2016). Different Roles of TNF Inhibitors in Acute Anterior Uveitis Associated With Ankylosing Spondylitis: State of the Art. Clin. Rheumatol. 35 (11), 2631-2638. doi:10.1007/s10067-016-3426-3

Feldmann, M., and Maini, R. N. (2003). Lasker Clinical Medical Research Award. TNF Defined as a Therapeutic Target for Rheumatoid Arthritis and Other Autoimmune Diseases. Nat. Med. 9 (10), 1245-1250. doi:10.1038/nm939

Fleisher, L. N., Ferrell, J. B., Smith, M. G., and McGahan, M. C. (1991). Lipid Mediators of Tumor Necrosis Factor-Alpha-Induced Uveitis. Invest. Ophthalmol. Vis. Sci. 32 (8), 2393-2399.

Frei, K., Eugster, H. P., Bopst, M., Constantinescu, C. S., Lavi, E., and Fontana, A. (1997). Tumor Necrosis Factor Alpha and Lymphotoxin Alpha Are Not
Required for Induction of Acute Experimental Autoimmune Encephalomyelitis. J. Exp. Med. 185 (12), 2177-2182. doi:10.1084/ jem.185.12.2177

Gery, I., Chanaud, N. P., 3rd, and Anglade, E. (1994). Recoverin Is Highly Uveitogenic in Lewis Rats. Invest. Ophthalmol. Vis. Sci. 35 (8), 3342-3345.

Gray, P. W., Aggarwal, B. B., Benton, C. V., Bringman, T. S., Henzel, W. J., Jarrett, J. A., et al. (1984). Cloning and Expression of cDNA for Human Lymphotoxin, a Lymphokine With Tumour Necrosis Activity. Nature. 312 (5996), 721-724. doi:10.1038/312721a0

Grell, M., Douni, E., Wajant, H., Löhden, M., Clauss, M., Maxeiner, B., et al. (1995). The Transmembrane Form of Tumor Necrosis Factor Is the Prime Activating Ligand of the $80 \mathrm{kDa}$ Tumor Necrosis Factor Receptor. Cell. 83 (5), 793-802. doi:10.1016/0092-8674(95)90192-2

Gritz, D. C., and Wong, I. G. (2004). Incidence and Prevalence of Uveitis in Northern California; the Northern California Epidemiology of Uveitis Study. Ophthalmology. 111 (3), 491-500. doi:10.1016/j.ophtha.2003.06.014

Hankey, D. J., Lightman, S. L., and Baker, D. (2001). Interphotoreceptor Retinoid Binding Protein Peptide-Induced Uveitis in B10.RIII Mice: Characterization of Disease Parameters and Immunomodulation. Exp. Eye Res. 72 (3), 341-350. doi:10.1006/exer.2000.0957

Hasegawa, E., Takeda, A., Yawata, N., and Sonoda, K. H. (2019). The Effectiveness of Adalimumab Treatment for Non-Infectious Uveitis. Immunol. Med. 42 (2), 79-83. doi:10.1080/25785826.2019.1642080

Hatemi, G., Christensen, R., Bang, D., Bodaghi, B., Celik, A. F., Fortune, F., et al. (2018). 2018 Update of the EULAR Recommendations for the Management of Behçet's Syndrome. Ann. Rheum. Dis. 77 (6), 808-818. doi:10.1136/ annrheumdis-2018-213225

He, S., Wang, L., Miao, L., Wang, T., Du, F., Zhao, L., et al. (2009). Receptor Interacting Protein Kinase-3 Determines Cellular Necrotic Response to TNFAlpha. Cell. 137 (6), 1100-1111. doi:10.1016/j.cell.2009.05.021

Hermann, L., Falcão-Reis, F., and Figueira, L. (2021). Epidemiology of Uveitis in a Tertiary Care Centre in Portugal. Semin. Ophthalmol. 36 (1-2), 51-57. doi:10.1080/08820538.2021.1885721

Hohmann, H. P., Remy, R., Brockhaus, M., and van Loon, A. P. (1989). Two Different Cell Types Have Different Major Receptors for Human Tumor Necrosis Factor (TNF Alpha). J. Biol. Chem. 264 (25), 14927-14934. doi:10.1016/s0021-9258(18)63791-3

Holtkamp, G. M., Kijlstra, A., Peek, R., and de Vos, A. F. (2001). Retinal Pigment Epithelium-Immune System Interactions: Cytokine Production and CytokineInduced Changes. Prog. Retin. Eye Res. 20 (1), 29-48. doi:10.1016/s13509462(00)00017-3

Hsu, H., Xiong, J., and Goeddel, D. V. (1995). The TNF Receptor 1-Associated Protein TRADD Signals Cell Death and NF-Kappa B Activation. Cell. 81 (4), 495-504. doi:10.1016/0092-8674(95)90070-5

Hu, Y., Huang, Z., Yang, S., Chen, X., Su, W., and Liang, D. (2020). Effectiveness and Safety of Anti-Tumor Necrosis Factor-Alpha Agents Treatment in Behcets' Disease-Associated Uveitis: A Systematic Review and Meta-Analysis. Front. Pharmacol. 11, 941. doi:10.3389/fphar.2020.00941

Huang, Y., He, J., Liang, H., Hu, K., Jiang, S., Yang, L., et al. (2018). Aryl Hydrocarbon Receptor Regulates Apoptosis and Inflammation in a Murine Model of Experimental Autoimmune Uveitis. Front. Immunol. 9, 1713. doi:10.3389/fimmu.2018.01713

Iademarco, M. F., Barks, J. L., and Dean, D. C. (1995). Regulation of Vascular Cell Adhesion Molecule-1 Expression by IL-4 and TNFAlpha in Cultured Endothelial Cells. J. Clin. Invest. 95 (1), 264-271. doi: $10.1172 /$ jci117650

Izumi-Nagai, K., Nagai, N., Ohgami, K., Satofuka, S., Ozawa, Y., Tsubota, K., et al. (2007). Macular Pigment Lutein Is Antiinflammatory in Preventing Choroidal Neovascularization. Arterioscler Thromb. Vasc. Biol. 27 (12), 2555-2562. doi:10.1161/atvbaha.107.151431

Jabs, D. A., Nussenblatt, R. B., and Rosenbaum, J. T. (2005). Standardization of Uveitis Nomenclature for Reporting Clinical Data. Results of the First International Workshop. Am. J. Ophthalmol. 140 (3), 509-516. doi:10.1016/ j.ajo.2005.03.057

Jaffe, G. J., Dick, A. D., Brézin, A. P., Nguyen, Q. D., Thorne, J. E., Kestelyn, P., et al. (2016). Adalimumab in Patients With Active Noninfectious Uveitis. N. Engl. J. Med. 375 (10), 932-943. doi:10.1056/NEJMoa1509852 
Jakob, E., Reuland, M. S., Mackensen, F., Harsch, N., Fleckenstein, M., Lorenz, H. M., et al. (2009). Uveitis Subtypes in a German Interdisciplinary Uveitis Center--Analysis of 1916 Patients. J. Rheumatol. 36 (1), 127-136. doi:10.3899/jrheum.080102

Jha, P., Matta, B., Lyzogubov, V., Tytarenko, R., Bora, P. S., and Bora, N. S. (2007). Crucial Role of Apoptosis in the Resolution of Experimental Autoimmune Anterior Uveitis. Invest. Ophthalmol. Vis. Sci. 48 (11), 5091-5100. doi:10.1167/ iovs.07-0651

Joseph, A., Raj, D., Dua, H. S., Powell, P. T., Lanyon, P. C., and Powell, R. J. (2003). Infliximab in the Treatment of Refractory Posterior Uveitis. Ophthalmology. 110 (7), 1449-1453. doi:10.1016/s0161-6420(03)00406-8

Kasner, L., Chan, C. C., Whitcup, S. M., and Gery, I. (1993). The Paradoxical Effect of Tumor Necrosis Factor Alpha (TNF-Alpha) in Endotoxin-Induced Uveitis. Invest. Ophthalmol. Vis. Sci. 34 (10), 2911-2917.

Kaufmann, T., Strasser, A., and Jost, P. J. (2012). Fas Death Receptor Signalling: Roles of Bid and XIAP. Cell Death Differ. 19 (1), 42-50. doi:10.1038/ cdd.2011.121

Keffer, J., Probert, L., Cazlaris, H., Georgopoulos, S., Kaslaris, E., Kioussis, D., et al. (1991). Transgenic Mice Expressing Human Tumour Necrosis Factor: a Predictive Genetic Model of Arthritis. Embo j. 10 (13), 4025-4031. doi:10.1002/j.1460-2075.1991.tb04978.x

Keino, H., Nakashima, C., Watanabe, T., Taki, W., Hayakawa, R., Sugitani, A., et al. (2009). Frequency and Clinical Features of Intraocular Inflammation in Tokyo. Clin. Exp. Ophthalmol. 37 (6), 595-601. doi:10.1111/j.1442-9071.2009.02102.x

Kelker, H. C., Oppenheim, J. D., Stone-Wolff, D., Henriksen-DeStefano, D., Aggarwal, B. B., Stevenson, H. C., et al. (1985). Characterization of Human Tumor Necrosis Factor Produced by Peripheral Blood Monocytes and its Separation From Lymphotoxin. Int. J. Cancer. 36 (1), 69-73. doi:10.1002/ ijc. 2910360112

Kijlstra, A., Tian, Y., Kelly, E. R., and Berendschot, T. T. (2012). Lutein: More Than Just a Filter for Blue Light. Prog. Retin. Eye Res. 31 (4), 303-315. doi:10.1016/ j.preteyeres.2012.03.002

Koizumi, K., Poulaki, V., Doehmen, S., Welsandt, G., Radetzky, S., Lappas, A., et al. (2003). Contribution of TNF-Alpha to Leukocyte Adhesion, Vascular Leakage, and Apoptotic Cell Death in Endotoxin-Induced Uveitis In Vivo. Invest. Ophthalmol. Vis. Sci. 44 (5), 2184-2191. doi:10.1167/iovs.02-0589

Komander, D., and Rape, M. (2012). The Ubiquitin Code. Annu. Rev. Biochem. 81, 203-229. doi:10.1146/annurev-biochem-060310-170328

Komander, D., Reyes-Turcu, F., Licchesi, J. D., Odenwaelder, P., Wilkinson, K. D., and Barford, D. (2009). Molecular Discrimination of Structurally Equivalent Lys 63-Linked and Linear Polyubiquitin Chains. EMBO Rep. 10 (5), 466-473. doi:10.1038/embor.2009.55

Kovalenko, A., Chable-Bessia, C., Cantarella, G., Israël, A., Wallach, D., and Courtois, G. (2003). The Tumour Suppressor CYLD Negatively Regulates NF-KappaB Signalling by Deubiquitination. Nature. 424 (6950), 801-805. doi:10.1038/nature01802

Krippner-Heidenreich, A., Tübing, F., Bryde, S., Willi, S., Zimmermann, G., and Scheurich, P. (2002). Control of Receptor-Induced Signaling Complex Formation by the Kinetics of Ligand/Receptor Interaction. J. Biol. Chem. 277 (46), 44155-44163. doi:10.1074/jbc.M207399200

Lafont, E., Draber, P., Rieser, E., Reichert, M., Kupka, S., de Miguel, D., et al. (2018). TBK1 and IKKe Prevent TNF-Induced Cell Death by RIPK1 Phosphorylation. Nat. Cell Biol. 20 (12), 1389-1399. doi:10.1038/s41556-018-0229-6

Larsen, C. G., Anderson, A. O., Oppenheim, J. J., and Matsushima, K. (1989a). Production of Interleukin- 8 by Human Dermal Fibroblasts and Keratinocytes in Response to Interleukin-1 or Tumour Necrosis Factor. Immunology. 68 (1), 31-36.

Larsen, C. G., Zachariae, C. O., Oppenheim, J. J., and Matsushima, K. (1989b). Production of Monocyte Chemotactic and Activating Factor (MCAF) by Human Dermal Fibroblasts in Response to Interleukin 1 or Tumor Necrosis Factor. Biochem. Biophys. Res. Commun. 160 (3), 1403-1408. doi:10.1016/ s0006-291x(89)80160-3

Leal, I., Rodrigues, F. B., Sousa, D. C., Duarte, G. S., Romão, V. C., Marques-Neves, C., et al. (2019). Anti-TNF Drugs for Chronic Uveitis in Adults-A Systematic Review and Meta-Analysis of Randomized Controlled Trials. Front. Med. (Lausanne). 6, 104. doi:10.3389/fmed.2019.00104

Leclercq, M., Langlois, V., Girszyn, N., Le Besnerais, M., Benhamou, Y., Levesque, H., et al. (2020). Comparison of Conventional Immunosuppressive Drugs versus Anti-TNF- $\alpha$ Agents in Non-infectious Non-Anterior Uveitis. J. Autoimmun. 113, 102481. doi:10.1016/j.jaut.2020.102481

Lee, I. Y., Lim, J. M., Cho, H., Kim, E., Kim, Y., Oh, H. K., et al. (2019). MST1 Negatively Regulates TNFa-Induced NF-Kb Signaling Through Modulating LUBAC Activity. Mol. Cell. 73 (6), 1138-e6. el136. doi:10.1016/ j.molcel.2019.01.022

Levy-Clarke, G., Jabs, D. A., Read, R. W., Rosenbaum, J. T., Vitale, A., and Van Gelder, R. N. (2014). Expert Panel Recommendations for the Use of Anti-tumor Necrosis Factor Biologic Agents in Patients With Ocular Inflammatory Disorders. Ophthalmology. 121 (3), 785-e3. doi:10.1016/j.ophtha.2013.09.048

Li, H., Yoneda, M., Takeyama, M., Sugita, I., Tsunekawa, H., Yamada, H., et al. (2010a). Effect of Infliximab on Tumor Necrosis Factor-Alpha-Induced Alterations in Retinal Microvascular Endothelial Cells and Retinal Pigment Epithelial Cells. J. Ocul. Pharmacol. Ther. 26 (6), 549-556. doi:10.1089/ jop.2010.0079

Li, S., Lu, H., Hu, X., Chen, W., Xu, Y., and Wang, J. (2010b). Expression of TLR4MyD88 and NF-Kb in the Iris During Endotoxin-Induced Uveitis. Mediators Inflamm. 2010, 748218. doi:10.1155/2010/748218

Li, J., McQuade, T., Siemer, A. B., Napetschnig, J., Moriwaki, K., Hsiao, Y. S., et al. (2012). The RIP1/RIP3 Necrosome Forms a Functional Amyloid Signaling Complex Required for Programmed Necrosis. Cell. 150 (2), 339-350. doi:10.1016/j.cell.2012.06.019

Liang, W. C., Ren, J. L., Yu, Q. X., Li, J., Ng, T. K., Chu, W. K., et al. (2020). Signaling Mechanisms of Growth Hormone-Releasing Hormone Receptor in LPSInduced Acute Ocular Inflammation. Proc. Natl. Acad. Sci. U S A. 117 (11), 6067-6074. doi:10.1073/pnas.1904532117

Lichtenstein, L., Ron, Y., Kivity, S., Ben-Horin, S., Israeli, E., Fraser, G. M., et al. (2015). Infliximab-Related Infusion Reactions: Systematic Review. J. Crohns Colitis. 9 (9), 806-815. doi:10.1093/ecco-jcc/jjv096

Liu, R., He, X., Geng, W., Wang, T., and Ruan, Q. (2019). Loss of TIPE2 Has Opposing Effects on the Pathogenesis of Autoimmune Diseases. Front. Immunol. 10, 2284. doi:10.3389/fimmu.2019.02284

Liversidge, J., Dick, A., Daniels, G., and Dawson, R. (2000). Induction or Suppression of a B Cell-specific Response to Self Antigen In Vivo Is Dependent upon Dendritic Cell Activation via the TNF-Alpha Receptor at the Time of Antigen Uptake. Eur. J. Immunol. 30 (8), 2268-2280. doi:10.1002/ 1521-4141(2000)30:8<2268:Aid-immu2268>3.0.Co;2-m

Liversidge, J., Dick, A., and Gordon, S. (2002). Nitric Oxide Mediates Apoptosis Through Formation of Peroxynitrite and Fas/Fas-Ligand Interactions in Experimental Autoimmune Uveitis. Am. J. Pathol. 160 (3), 905-916. doi:10.1016/s0002-9440(10)64913-9

Llorenç, V., Cordero-Coma, M., Blanco-Esteban, A., Heras-Mulero, H., LosadaCastillo, M. J., Jovani-Casano, V., et al. (2020). Drug Retention Rate and Causes of Discontinuation of Adalimumab in Uveitis: Real-World Data From the Biotherapies in Uveitis (BioÚvea) Study Group. Ophthalmology. 127 (6), 814-825. doi:10.1016/j.ophtha.2019.11.024

Llorenç, V., Mesquida, M., Sainz de la Maza, M., Blanco, R., Calvo, V., Maíz, O., et al. (2016). Certolizumab Pegol, a New Anti-TNF- $\alpha$ in the Armamentarium Against Ocular Inflammation. Ocul. Immunol. Inflamm. 24 (2), 167-172. doi:10.3109/09273948.2014.967779

Llorenç, V., Mesquida, M., Sainz de la Maza, M., Keller, J., Molins, B., Espinosa, G., et al. (2015). Epidemiology of Uveitis in a Western Urban Multiethnic Population. The challenge of Globalization. Acta Ophthalmol. 93 (6), 561-567. doi:10.1111/aos.12675

Luca, C., Raffaella, A., Sylvia, M., Valentina, M., Fabiana, V., Marco, C., et al. (2018). Changes in Patterns of Uveitis at a Tertiary Referral center in Northern Italy: Analysis of 990 Consecutive Cases. Int. Ophthalmol. 38 (1), 133-142. doi:10.1007/s10792-016-0434-x

Luna, J. D., Chan, C. C., Derevjanik, N. L., Mahlow, J., Chiu, C., Peng, B., et al. (1997). Blood-Retinal Barrier (BRB) Breakdown in Experimental Autoimmune Uveoretinitis: Comparison With Vascular Endothelial Growth Factor, Tumor Necrosis Factor Alpha, and Interleukin-1beta-Mediated Breakdown. J. Neurosci. Res. 49 (3), 268-280. doi:10.1002/(sici)1097-4547(19970801)49: $3<268$ :aid-jnr2 $>3.0$.co;2-a

MacEwan, D. J. (2002). TNF Ligands and Receptors-Aa Matter of Life and Death. Br. J. Pharmacol. 135 (4), 855-875. doi:10.1038/sj.bjp.0704549

Mariette, X., Förger, F., Abraham, B., Flynn, A. D., Moltó, A., Flipo, R. M., et al. (2018). Lack of Placental Transfer of Certolizumab Pegol During Pregnancy: 
Results From CRIB, a Prospective, Postmarketing, Pharmacokinetic Study. Ann. Rheum. Dis. 77 (2), 228-233. doi:10.1136/annrheumdis-2017-212196

Markomichelakis, N., Delicha, E., Masselos, S., Fragiadaki, K., Kaklamanis, P., and Sfikakis, P. P. (2011). A Single Infliximab Infusion vs Corticosteroids for Acute Panuveitis Attacks in Behçet's Disease: a Comparative 4-Week Study. Rheumatology (Oxford). 50 (3), 593-597. doi:10.1093/rheumatology/keq366

Masters, S. L., Simon, A., Aksentijevich, I., and Kastner, D. L. (2009). Horror Autoinflammaticus: the Molecular Pathophysiology of Autoinflammatory Disease $\left({ }^{*}\right)$. Annu. Rev. Immunol. 27, 621-668. doi:10.1146/ annurev.immunol.25.022106.141627

Mei, S., Huang, Y., Li, N., Xu, Z., Xu, J., Dai, Q., et al. (2020). Aminooxy-Acetic Acid Inhibits Experimental Autoimmune Uveitis by Modulating the Balance Between Effector and Regulatory Lymphocyte Subsets. Curr. Mol. Med. 20 (8), 624-632. doi:10.2174/1566524020666200211112219

Meka, R. R., Venkatesha, S. H., Dudics, S., Acharya, B., and Moudgil, K. D. (2015). IL-27-Induced Modulation of Autoimmunity and its Therapeutic Potential. Autoimmun. Rev. 14 (12), 1131-1141. doi:10.1016/j.autrev.2015.08.001

Meng, X., Fang, S., Zhang, Z., Wang, Y., You, C., Zhang, J., et al. (2017). Preventive Effect of Chrysin on Experimental Autoimmune Uveitis Triggered by Injection of Human IRBP Peptide 1-20 in Mice. Cell Mol Immunol. 14 (8), 702-711. doi:10.1038/cmi.2015.107

Meyer, F. A., Yaron, I., and Yaron, M. (1990). Synergistic, Additive, and Antagonistic Effects of Interleukin-1 Beta, Tumor Necrosis Factor Alpha, and Gamma-Interferon on Prostaglandin E, Hyaluronic Acid, and Collagenase Production by Cultured Synovial Fibroblasts. Arthritis Rheum. 33 (10), 1518-1525. doi:10.1002/art.1780331009

Micheau, O., and Tschopp, J. (2003). Induction of TNF Receptor I-Mediated Apoptosis via Two Sequential Signaling Complexes. Cell. 114 (2), 181-190. doi:10.1016/s0092-8674(03)00521-x

Ming, S., Xie, K., He, H., Li, Y., and Lei, B. (2018). Efficacy and Safety of Adalimumab in the Treatment of Non-Infectious Uveitis: a Meta-Analysis and Systematic Review. Drug Des. Devel Ther. 12, 2005-2016. doi:10.2147/ dddt.S160431

Mitulescu, T. C., Trandafir, M., Dimăncescu, M. G., Ciuluvică, R. C., Popescu, V., Predețeanu, D., et al. (2018). Advances in the Treatment of Uveitis in Patients With Spondyloarthritis - Is it the Time for Biologic Therapy? Rom. J. Ophthalmol. 62 (2), 114-122. doi:10.22336/rjo.2018.17

Moll-Udina, A., Miguel Escuder, L., Hernanz, I., Llorenç, V., Fonollosa, A., Cordero Coma, M., et al. (2020). Adalimumab in Elderly Patients With Non-Infectious Uveitis. Safety and Efficacy. Ocul. Immunol. Inflamm., 1-8. doi:10.1080/09273948.2020.1769139

Motulsky, E., Koch, P., Janssens, S., Liénart, M., Vanbellinghen, A. M., Bolaky, N., et al. (2010). Aquaporin Expression in Blood-Retinal Barrier Cells During Experimental Autoimmune Uveitis. Mol. Vis. 16, 602-610.

Muñoz-Fernández, S., Hidalgo, V., Fernández-Melón, J., Schlincker, A., and Martín-Mola, E. (2001). Effect of Infliximab on Threatening Panuveitis in Behçet's Disease. Lancet. 358 (9293), 1644. doi:10.1016/s0140-6736(01)06677-6

Nakamura, H., Yamaki, K., Kondo, I., and Sakuragi, S. (2005). Experimental Autoimmune Uveitis Induced by Immunization With Retinal Pigment Epithelium-Specific 65-kDa Protein Peptides. Curr. Eye Res. 30 (8), 673-680. doi:10.1080/02713680590968330

Nakamura, S., Yamakawa, T., Sugita, M., Kijima, M., Ishioka, M., Tanaka, S., et al. (1994). The Role of Tumor Necrosis Factor-Alpha in the Induction of Experimental Autoimmune Uveoretinitis in Mice. Invest. Ophthalmol. Vis. Sci. 35 (11), 3884-3889.

Nguyen, Q. D., Merrill, P. T., Jaffe, G. J., Dick, A. D., Kurup, S. K., Sheppard, J., et al. (2016). Adalimumab for Prevention of Uveitic Flare in Patients With Inactive Non-Infectious Uveitis Controlled by Corticosteroids (VISUAL II): a Multicentre, Double-Masked, Randomised, PlaceboControlled Phase 3 Trial. Lancet. 388 (10050), 1183-1192. doi:10.1016/s0140-6736(16)31339-3

Nityanand, S., Singh, V. K., Shinohara, T., Paul, A. K., Singh, V., Agarwal, P. K., et al. (1993). Cellular Immune Response of Patients With Uveitis to Peptide M, a Retinal S-Antigen Fragment. J. Clin. Immunol. 13 (5), 352-358. doi:10.1007/ bf00920244

Nussenblatt, R. B. (1991). Proctor Lecture. Experimental Autoimmune Uveitis: Mechanisms of Disease and Clinical Therapeutic Indications. Invest. Ophthalmol. Vis. Sci. 32 (13), 3131-3141.
O'Malley, W. E., Achinstein, B., and Shear, M. J. (1988). Journal of the National Cancer Institute, Vol. 29, 1962: Action of Bacterial Polysaccharide on Tumors. II. Damage of Sarcoma 37 by Serum of Mice Treated with Serratia marcescens Polysaccharide, and Induced toleranceAction of Bacterial Polysaccharide on Tumors. II. Damage of Sarcoma 37 by Serum of Mice Treated with Serratia marcescens Polysaccharide, and Induced Tolerance. Nutr. Rev. 2946 (11), 389-391. doi:10.1111/j.1753-4887.1988.tb05376.x

Pasparakis, M., and Vandenabeele, P. (2015). Necroptosis and its Role in Inflammation. Nature. 517 (7534), 311-320. doi:10.1038/nature14191

Pennica, D., Nedwin, G. E., Hayflick, J. S., Seeburg, P. H., Derynck, R., Palladino, M. A., et al. (1984). Human Tumour Necrosis Factor: Precursor Structure, Expression and Homology to Lymphotoxin. Natur 312 (5996), 724-729. doi:10.1038/312724a0

Pober, J. S., Gimbrone, M. A., Jr., Lapierre, L. A., Mendrick, D. L., Fiers, W., Rothlein, R., et al. (1986). Overlapping Patterns of Activation of Human Endothelial Cells by Interleukin 1, Tumor Necrosis Factor, and Immune Interferon. J. Immunol. 137 (6), 1893-1896.

Prieto-Peña, D., Calderón-Goercke, M., Adán, A., Chamorro-López, L., MaízAlonso, O., De Dios-Jiménez Aberásturi, J. R., et al. (2021). Efficacy and Safety of Certolizumab Pegol in Pregnant Women With Uveitis. Recommendations on the Management with Immunosuppressive and Biologic Therapies in Uveitis During Pregnancy. Clin. Exp. Rheumatol. 39 (1), 105-114.

Ramanan, A. V., Dick, A. D., Jones, A. P., McKay, A., Williamson, P. R., Compeyrot-Lacassagne, S., et al. (2017). Adalimumab Plus Methotrexate for Uveitis in Juvenile Idiopathic Arthritis. N. Engl. J. Med. 376 (17), 1637-1646. doi:10.1056/NEJMoa1614160

Robertson, M., Liversidge, J., Forrester, J. V., and Dick, A. D. (2003). Neutralizing Tumor Necrosis Factor-Alpha Activity Suppresses Activation of Infiltrating Macrophages in Experimental Autoimmune Uveoretinitis. Invest. Ophthalmol. Vis. Sci. 44 (7), 3034-3041. doi:10.1167/iovs.02-1156

Ruddle, N. H., Bergman, C. M., McGrath, K. M., Lingenheld, E. G., Grunnet, M. L., Padula, S. J., et al. (1990). An Antibody to Lymphotoxin and Tumor Necrosis Factor Prevents Transfer of Experimental Allergic Encephalomyelitis. J. Exp. Med. 172 (4), 1193-1200. doi:10.1084/jem.172.4.1193

Rudwaleit, M., Rosenbaum, J. T., Landewé, R., Marzo-Ortega, H., Sieper, J., van der Heijde, D., et al. (2016). Observed Incidence of Uveitis Following Certolizumab Pegol Treatment in Patients With Axial Spondyloarthritis. Arthritis Care Res. (Hoboken). 68 (6), 838-844. doi:10.1002/acr.22848

Sancéau, J., Falcoff, R., Beranger, F., Carter, D. B., and Wietzerbin, J. (1990). Secretion of Interleukin-6 (IL-6) by Human Monocytes Stimulated by Muramyl Dipeptide and Tumour Necrosis Factor Alpha. Immunology. 69 (1), 52-56.

Sandborn, W. J., Hanauer, S. B., Katz, S., Safdi, M., Wolf, D. G., Baerg, R. D., et al. (2001). Etanercept for Active Crohn's Disease: a Randomized, Double-Blind, Placebo-Controlled Trial. Gastroenterology. 121 (5), 1088-1094. doi:10.1053/ gast.2001.28674

Sartani, G., Silver, P. B., Rizzo, L. V., Chan, C. C., Wiggert, B., Mastorakos, G., et al. (1996). Anti-Tumor Necrosis Factor Alpha Therapy Suppresses the Induction of Experimental Autoimmune Uveoretinitis in Mice by Inhibiting Antigen Priming. Invest. Ophthalmol. Vis. Sci. 37 (11), 2211-2218.

Schall, T. J., Lewis, M., Koller, K. J., Lee, A., Rice, G. C., Wong, G. H., et al. (1990). Molecular Cloning and Expression of a Receptor for Human Tumor Necrosis Factor. Cell. 61 (2), 361-370. doi:10.1016/0092-8674(90)90816-w

Sfikakis, P. P., Theodossiadis, P. G., Katsiari, C. G., Kaklamanis, P., and Markomichelakis, N. N. (2001). Effect of Infliximab on Sight-Threatening Panuveitis in Behçet's Disease. Lancet. 358 (9278), 295-296. doi:10.1016/ s0140-6736(01)05497-6

Sharon, Y., and Chu, D. S. (2020). Certolizumab Pegol - Tumor Necrosis Factor Inhibitor for Refractory Uveitis. Am. J. Ophthalmol. Case Rep. 18, 100633. doi:10.1016/j.ajoc.2020.100633

Silke, J., and Brink, R. (2010). Regulation of TNFRSF and Innate Immune Signalling Complexes by TRAFs and cIAPs. Cell Death Differ. 17 (1), 35-45. doi:10.1038/cdd.2009.114

Sironi, M., Breviario, F., Proserpio, P., Biondi, A., Vecchi, A., Van Damme, J., et al. (1989). IL-1 Stimulates IL-6 Production in Endothelial Cells. J. Immunol. 142 (2), 549-553.

Smith, J. R., Hart, P. H., Coster, D. J., and Williams, K. A. (1998). Mice Deficient in Tumor Necrosis Factor Receptors P55 and P75, Interleukin-4, or Inducible 
Nitric Oxide Synthase Are Susceptible to Endotoxin-Induced Uveitis. Invest. Ophthalmol. Vis. Sci. 39 (3), 658-661.

Sobrin, L., Kim, E. C., Christen, W., Papadaki, T., Letko, E., and Foster, C. S. (2007). Infliximab Therapy for the Treatment of Refractory Ocular Inflammatory Disease. Arch. Ophthalmol. 125 (7), 895-900. doi:10.1001/ archopht.125.7.895

Sonoda, K. H., Hasegawa, E., Namba, K., Okada, A. A., Ohguro, N., and Goto, H. (2021). Epidemiology of Uveitis in Japan: a 2016 Retrospective Nationwide Survey. Jpn. J. Ophthalmol. 65 (2), 184-190. doi:10.1007/s10384-020-00809-1

Sota, J., Gentileschi, S., Vitale, A., Gaggiano, C., De Bartolo, G., Bianco, M. T., et al. (2021). Effectiveness of SB5, an Adalimumab Biosimilar, in Patients with Noninfectious Uveitis: A Real-Life Monocentric Experience. Asia Pac. J. Ophthalmol. (Phila). 10, 360-365. doi:10.1097/apo.0000000000000380

Sugita, S., Kawazoe, Y., Imai, A., Yamada, Y., Horie, S., and Mochizuki, M. (2012). Inhibition of Th17 Differentiation by Anti-TNF-alpha Therapy in Uveitis Patients with Behçet's Disease. Arthritis Res. Ther. 14 (3), R99. doi:10.1186/ $\operatorname{ar} 3824$

Sugita, S., Takase, H., Taguchi, C., and Mochizuki, M. (2007). The Role of Soluble TNF Receptors for TNF-Alpha in Uveitis. Invest. Ophthalmol. Vis. Sci. 48 (7), 3246-3252. doi:10.1167/iovs.06-1444

Suzuki, Y., Ohgami, K., Shiratori, K., Jin, X. H., Ilieva, I., Koyama, Y., et al. (2006). Suppressive Effects of Astaxanthin Against Rat Endotoxin-Induced Uveitis by Inhibiting the NF-kappaB Signaling Pathway. Exp. Eye Res. 82 (2), 275-281. doi:10.1016/j.exer.2005.06.023

Tosi, G. M., Sota, J., Vitale, A., Rigante, D., Emmi, G., Lopalco, G., et al. (2019). Efficacy and Safety of Certolizumab Pegol and Golimumab in the Treatment of Non-infectious Uveitis. Clin. Exp. Rheumatol. 37 (4), 680-683.

Touhami, S., Diwo, E., Sève, P., Trad, S., Bielefeld, P., Sène, D., et al. (2019). Expert Opinion on the Use of Biological Therapy in Non-Infectious Uveitis. Expert Opin. Biol. Ther. 19 (5), 477-490. doi:10.1080/ 14712598.2019.1595578

Tracey, D., Klareskog, L., Sasso, E. H., Salfeld, J. G., and Tak, P. P. (2008). Tumor Necrosis Factor Antagonist Mechanisms of Action: a Comprehensive Review. Pharmacol. Ther. 117 (2), 244-279. doi:10.1016/j.pharmthera.2007.10.001

Tracey, K. J., Fong, Y., Hesse, D. G., Manogue, K. R., Lee, A. T., Kuo, G. C., et al. (1987). Anti-cachectin/TNF Monoclonal Antibodies Prevent Septic Shock During Lethal Bacteraemia. Nature. 330 (6149), 662-664. doi:10.1038/ 330662a0

Tugal-Tutkun, I., Mudun, A., Urgancioglu, M., Kamali, S., Kasapoglu, E., Inanc, M., et al. (2005). Efficacy of Infliximab in the Treatment of Uveitis that Is Resistant to Treatment With the Combination of Azathioprine, Cyclosporine, and Corticosteroids in Behçet's Disease: an Open-Label Trial. Arthritis Rheum. 52 (8), 2478-2484. doi:10.1002/art.21231

Vallet, H., Riviere, S., Sanna, A., Deroux, A., Moulis, G., Addimanda, O., et al. (2015). Efficacy of Anti-TNF Alpha in Severe And/or Refractory Behçet's Disease: Multicenter Study of 124 Patients. J. Autoimmun. 62, 67-74. doi:10.1016/j.jaut.2015.06.005

Vallet, H., Seve, P., Biard, L., Baptiste Fraison, J., Bielefeld, P., Perard, L., et al. (2016). Infliximab Versus Adalimumab in the Treatment of Refractory Inflammatory Uveitis: A Multicenter Study From the French Uveitis Network. Arthritis Rheumatol. 68 (6), 1522-1530. doi:10.1002/art.39667

Valone, F. H., and Epstein, L. B. (1988). Biphasic Platelet-Activating Factor Synthesis by Human Monocytes Stimulated With IL-1-beta, Tumor Necrosis Factor, or IFN-Gamma. J. Immunol. 141 (11), 3945-3950.

Vandenabeele, P., Galluzzi, L., Vanden Berghe, T., and Kroemer, G. (2010). Molecular Mechanisms of Necroptosis: an Ordered Cellular Explosion. Nat. Rev. Mol. Cell Biol. 11 (10), 700-714. doi:10.1038/nrm2970

Vassalli, P. (1992). The Pathophysiology of Tumor Necrosis Factors. Annu. Rev. Immunol. 10, 411-452. doi:10.1146/annurev.iy.10.040192.002211
Wacker, W. B., and Lipton, M. M. (1965). Experimental Allergic Uveitis: Homologous Retina as Uveitogenic Antigen. Nature. 206 (981), 253-254. doi:10.1038/206253a0

Wang, L., Du, F., and Wang, X. (2008). TNF-alpha Induces Two Distinct Caspase-8 Activation Pathways. Cell. 133 (4), 693-703. doi:10.1016/j.cell.2008.03.036

Wang, L., Xu, Y., Yu, Q., Sun, Q., Xu, Y., Gu, Q., et al. (2014). H-RN, a Novel Antiangiogenic Peptide Derived From Hepatocyte Growth Factor Inhibits Inflammation In Vitro and In Vivo through PI3K/AKT/IKK/NF- $\mathrm{BB}$ Signal Pathway. Biochem. Pharmacol. 89 (2), 255-265. doi:10.1016/ j.bcp.2014.02.026

Watanabe, T., Keino, H., Sato, Y., Kudo, A., Kawakami, H., and Okada, A. A. (2009). High Mobility Group Box Protein-1 in Experimental Autoimmune Uveoretinitis. Invest. Ophthalmol. Vis. Sci. 50 (5), 2283-2290. doi:10.1167/ iovs.08-2709

Yadav, U. C., Shoeb, M., Srivastava, S. K., and Ramana, K. V. (2011). Aldose Reductase Deficiency Protects from Autoimmune- and Endotoxin-Induced Uveitis in Mice. Invest. Ophthalmol. Vis. Sci. 52 (11), 8076-8085. doi:10.1167/ iovs.11-7830

Yamamoto, J. H., Minami, M., Inaba, G., Masuda, K., and Mochizuki, M. (1993). Cellular Autoimmunity to Retinal Specific Antigens in Patients With Behçet's Disease. Br. J. Ophthalmol. 77 (9), 584-589. doi:10.1136/ bjo.77.9.584

Yang, S., Huang, Z., Hu, Y., Zhang, J., Liu, X., Li, H., et al. (2021a). The Efficacy of Adalimumab as an Initial Treatment in Patients With Behçet's Retinal Vasculitis. Front. Pharmacol. 12, 609148. doi:10.3389/fphar.2021.609148

Yang, S., Huang, Z., Liu, X., Li, H., Xie, L., Chen, X., et al. (2021b). Comparative Study of Adalimumab Versus Conventional Therapy in Sight-Threatening Refractory Behçet's Uveitis With Vasculitis. Int. Immunopharmacol. 93, 107430. doi:10.1016/j.intimp.2021.107430

Yumnamcha, T., Devi, T. S., and Singh, L. P. (2019). Auranofin Mediates Mitochondrial Dysregulation and Inflammatory Cell Death in Human Retinal Pigment Epithelial Cells: Implications of Retinal Neurodegenerative Diseases. Front. Neurosci. 13, 1065. doi:10.3389/fnins.2019.01065

Zavoico, G. B., Ewenstein, B. M., Schafer, A. I., and Pober, J. S. (1989). IL-1 and Related Cytokines Enhance Thrombin-Stimulated PGI2 Production in Cultured Endothelial Cells Without Affecting Thrombin-Stimulated von Willebrand Factor Secretion or Platelet-Activating Factor Biosynthesis. J. Immunol. 142 (11), 3993-3999.

Conflict of Interest: The authors declare that the research was conducted in the absence of any commercial or financial relationships that could be construed as a potential conflict of interest.

The handling editor is currently organizing a Research Topic with one of the authors WS.

Publisher's Note: All claims expressed in this article are solely those of the authors and do not necessarily represent those of their affiliated organizations, or those of the publisher, the editors and the reviewers. Any product that may be evaluated in this article, or claim that may be made by its manufacturer, is not guaranteed or endorsed by the publisher.

Copyright $\odot 2021$ Jiang, Li, Tao, Duan, Wang and Su. This is an open-access article distributed under the terms of the Creative Commons Attribution License (CC BY). The use, distribution or reproduction in other forums is permitted, provided the original author(s) and the copyright owner(s) are credited and that the original publication in this journal is cited, in accordance with accepted academic practice. No use, distribution or reproduction is permitted which does not comply with these terms. 